\begin{tabular}{|l|c|c|c|r|}
\hline $\begin{array}{l}\text { Cuadernos de Investigación Geográfica } \\
\text { Geographical Research Letters }\end{array}$ & 2018 & N $^{\circ} 44(1)$ & pp. 213-244 & $\begin{array}{r}\text { ISSN 0211-6820 } \\
\text { eISSN 1697-9540 }\end{array}$ \\
\hline
\end{tabular}

DOI: http://doi.org/10.18172/cig.3399

(C) Universidad de La Rioja

\title{
SURGE GLACIERS DURING THE LITTLE ICE AGE IN THE PYRENEES
}

\author{
E. SERRANO ${ }^{1}$, R. MARTÍN-MORENO \\ ${ }^{1}$ Dpto. Geografía. Universidad de Valladolid, Spain. \\ ${ }^{2}$ Dpto. Didácticas Específicas, Universidad Autónoma de Madrid, Spain.
}

\begin{abstract}
Historical moraine complexes and erosional features are interesting elements to discern the historical climate changes and evolution, with a complex chronologies that help us to understand the dynamics and glacier evolution during the Little Ice Age (LIA). The existence of landforms as crevasses-squeeze ridges, hummocky moraines and flutes, related to different glacier advances and retreats, allows understanding in a better way the LIA glacier evolution in the Pyrenees. The aim of this work is to show how many LIA moraine complexes have traces offast flow ice; when the surge dynamic happened; his extent and the environmental meaning. Based on glacier landsystem analysis we have established a work hypothesis on the fast flow or surge dynamic glaciers during the LIA, with geomorphological features, as flutes and push and hummocky moraines, at least in 17 LIA glacier complexes. The analysis of morphosquences by fieldwork, photo interpretation and historical sources in 8 selected LIA moraine complexes have been compared with previous climatic reconstructions creating a hypothesis about the response of the LIA glaciers to the short time changes in temperature and moisture.

The glacier cirques with fast flow features are found in the highest mountains with summits above $3000 \mathrm{~m}$., mainly northern oriented (88\%) and without a significant lithology. The studied complexes (Central Infierno, Eastern Infierno, Oulettes de Gaube, Monte Perdido, Marboré, La Paúl, Literola and Tempestades) show 4 morphological units: a frontal moraine system (U1); a more voluminous moraine (U2); a little push and hummocky moraines complex linking with flutes (U3); and minor arcs up valley (U4). The U3 belongs to a fast flow stage or surging and by morphostratigraphy we can point out that the surge processes were produced between 1820 and 1840, at the end of the LIA. We related it with a possible climatic response to sudden cooling and the increase of winter precipitation with melt-water availability and quick ice melting during the summer, generating hydrodynamic changes in the small glaciers and quick dynamic response.
\end{abstract}

\section{Glaciares de oleada durante la Pequeña Edad del Hielo en los Pirineos}

RESUMEN. Los complejos morrénicos históricos de los Pirineos contienen elementos de interés para conocer los cambios climáticos históricos y su evolu- 
ción. La complejidad temporal que muestran permiten aproximarnos a la evolución y la dinámica de los glaciares durante la Pequeña Edad de Hielo (PEH). Además, la presencia de formas de modelado glaciar como crestas de compresión, morrenas hummocky y flutes señalan una dinámica glaciar definida por la presencia de flujos rápidos. La idea de este trabajo es mostrar la existencia de formas de modelado asociadas a flujos de hielo rápido o glaciares de oleada, así como su extensión, temporalidad y significado ambiental. Basados en el análisis de sistemas de formas glaciares (glacier landsystem), a partir de las huellas geomorfológicas como flutes, morrenas de empuje y morrenas hummocky en 17 complejos glaciares, se establece la existencia de flujos de hielo rápidos o glaciares de oleada durante la PEH. El análisis de morfosecuencias mediante trabajo de campo, fotointerpretación y fuentes históricas en 8 complejos morrénicos de la PEH y su comparación con reconstrucciones previas del clima en la Península Ibérica y Europa han permitido establecer como hipótesis una rápida respuesta de los glaciares a los breves cambios temporales de temperatura y humedad.

Los circos glaciares con huellas de flujos rápidos se sitúan en los macizos más altos, siempre con las cumbres por encima de $3000 \mathrm{~m}$, y están orientados prioritariamente al norte (88\%). Los complejos morrénicos estudiados (Infierno Central, Infierno Oriental, Oulettes de Gaube, Monte Perdido, Marboré, La Paúl, Literola y Tempestades) están formados por cuatro unidades morfológicas principales: un sistema de morrenas frontales (U1); morrenas laterales ofrontales más voluminosas (U2); complejos morrénicos menores con morrenas de empuje y hummocky que enlazan con flutes (U3); y arcos menores situados valle arriba (U4), no existentes en todos los casos. La Unidad 3 pertenece a una etapa con flujos rápidos del hielo o glaciares de oleada y a partir de la morfoestratigrafía se puede establecer que estos procesos se produjeron en torno a 1820-1840, en un lapso temporal de 20-35 años, ya al final de la PEH. Esta unidad la relacionamos con una posible respuesta climática a un enfriamiento repentino y al aumento de las precipitaciones invernales que incrementa la disponibilidad de agua de fusión nival y la rápida fusión del hielo durante el verano, generando rápidos cambios hidrodinámicos en los pequeños glaciares.

Key words: Glacial Landsystems, surge glaciers, Little Ice Age, flutes, Pyrenees.

Palabras clave: Sistemas de formas glaciares, oleadas glaciares, Pequeña Edad del Hielo, flutes, Pirineos.

*Corresponding author: Enrique Serrano, Departamento de Geografía, Universidad de Valladolid, España. E-mail address: serranoe@fyl.uva.es 


\section{Introduction}

Pyrenean glaciers developed around of the highest summits during the Little Ice Age (LIA), growing during near five centuries. Glaciers advanced forming cirque and tongue glaciers and modifying the present day high mountain by mean of new moraine complexes, over deepened basin or erosion on cirque walls. The LIA was the last glacier advance known, global and historical, that in the Iberian Peninsula only affected the highest mountains: Pyrenees, Cantabrian Mountains and Sierra Nevada (González Trueba et al., 2008; Hughes, 2014; Oliva et al., 2018). The proximity in time, the good conservation of landforms and the connection with the current glaciers and icepatches, make its study a field of growing interest. The LIA features and the moraine complexes are interesting elements to know the historical climate changes and evolution, the most used since Le Roy Ladurie looked for the LIA consequences in the historical sources and Alpine glaciers evolution. In the Iberian Peninsula until the 90s, the main information sources on LIA were the Pyrenean glaciers. The study of the LIA glaciers has been mainly focused on the glaciers existence, chronology and glacial retreat, related with the current glacier investigations (Nicolás, 1981; Martínez de Pisón and Arenillas, 1988; Serrano, 1988, 1991, 1996, 1998; Copons and Bordonau, 1994; Lampre, 1994, 1998; Grove and Gellalty, 1995; Chueca et al., 1998; López Moreno, 2000; Serrano et al., 2002; Grove, 2004; Martín-Moreno, 2006; González-Trueba et al., 2008; René, 2011; García-Ruiz et al., 2015; Martí et al., 2015). The LIA glacial evolution helps us to understand the dynamic and glacier evolution, in a period when both climate change responses and internal rheological variations of the ice masses were present. The existence of several morphologies associated with the different glacier advances and retreats -confirmed by fieldwork, aerial photography and historical references- help us to understand in a better way the LIA glacier evolution in the Pyrenees. The presence of different types of deposits and moraines, glacitectonic ridges, crevasses-squeeze ridges, hummocky moraines and flutes, show the behavior of the glaciers during the LIA within the glacier landsystem, as it has been defined in Evans (2003), context and morphosequence analysis.

Based on morphogenetic and morphoclimatic environments, several types of glacier landsystems in the Pyrenees could exist: "Active Temperate Glacial Landsystem" (ATGL), "Glaciated Valley Landsystem" (GVL) and "Surging Glacier Landsystem" (SGL), all of them characteristics of the temperate mountain environments (Evans et al., 2003; Benn and Evans, 2010).

The "Glaciated Valley Landsystem" (GVL, Table 1) is a compendium of common typologies of mountains such as the Pyrenees. In the external zone only in some cases are found eroded moraines with superimposed flutes and small hummocks (Benn et al., 2003). According to the same authors, the moraines show imbricate thrust, with thicker sediment layers (reaching dozens of meters) and flutes, usually associated with polythermal and surges glaciers, and in the margin of temperate glaciers (Benn and Evans, 2010). The GVL are characterized by the importance of the topography and landforms in the sediment transport, and also by the predominance of the supraglacial debris sources in the glacial sedimentary load, involving a great variety of associated landsystems (Benn et al., 2003). 
Table 1. Glaciated landsystem organization.

\begin{tabular}{|c|c|c|c|}
\hline \multirow{2}{*}{$\begin{array}{c}\text { Glacial } \\
\text { Landsystem }\end{array}$} & \multicolumn{3}{|c|}{ Glacial Environments } \\
\hline & Zone & & Processes and deposits \\
\hline \multirow{6}{*}{$\begin{array}{l}\text { Glaciated } \\
\text { Valley }{ }^{(1)} \\
\text { GVL }\end{array}$} & Erosive & \multicolumn{2}{|c|}{ Abrasion features on rocky outcrops } \\
\hline & Intermediate & \multicolumn{2}{|c|}{$\begin{array}{l}\text { Erosion and deposition, thin and disperse tills among the } \\
\text { rocky outcrops }\end{array}$} \\
\hline & \multirow{4}{*}{ External } & \multicolumn{2}{|c|}{ Continuous till coverage and subglacial traction till. } \\
\hline & & \multirow{3}{*}{$\begin{array}{l}\text { Three } \\
\text { sequential } \\
\text { environments }\end{array}$} & Marginal moraines \\
\hline & & & Subglacial \\
\hline & & & Glaciofluvial/glaciolacustrine \\
\hline \multirow{3}{*}{$\begin{array}{l}\text { Surge } \\
\text { Glacial }^{(2)} \\
\text { SGL }\end{array}$} & Proximal & \multicolumn{2}{|c|}{$\begin{array}{l}\text { Subglacial till, low amplitude flutes (crevasse-squeeze } \\
\text { ridges) and concertina eskers }\end{array}$} \\
\hline & Intermediate & \multicolumn{2}{|c|}{$\begin{array}{l}\text { Gradual transition to patchy hummocky moraine, push } \\
\text { moraines and thrust blocks }\end{array}$} \\
\hline & External & \multicolumn{2}{|c|}{$\begin{array}{l}\text { Formed by riding tills and push moraines (with deformed } \\
\text { pre-surge sediments) }\end{array}$} \\
\hline
\end{tabular}

(1) Boulton and Eyles, 1979; Benn et al., 2003. (2) Evans et al., 1999, 2007, 2009; Evans and Rea, 1999, 2003.

Surge glacial Landsystems (SGL, Table 1) are characterized by fast flows of ice, in very variable cyclical periods. Surging glaciers are defined as glaciers that accelerate suddenly (Benn and Evans, 2010), when their fronts advance annually o seasonally. This rapid advance produces high subglacial erosion over the soft bedded sediments, generating thrusts, folding, supraglacial debris, ice fractures due to the high water pressures and large areas of ice cored and hummocky moraines (Evans and Rea, 1999; 2003; Evans et al., 2007, 2009). In the SGL the three environment zones (Table 1) can be located contiguous or superimposed, and the most common features are concertina eskers, crevasses-squeeze ridges, flutes and hummocky moraines, blow out structures and ice-cored sandur. Some sources indicate that the combination of landforms and sediments, and their organization, is what define the terrestrial SGL thus enabling us to identify them (Evans et al., 1999; Evans and Rea, 2003; Benn and Evans, 2010; Brynjólfsson et al., 2014; Farnsworth et al., 2016).

Surges may be due to two mechanisms: hydrological switch model and thermal switch model (that one only for polythermal glaciers). The rapid advance of the temperate glaciers is linked to changes in the basal hydrology. Surges in temperate glaciers happen quickly and with a short duration (when compared with the polythermal ones), which means the presence of an important amount of meltwater responsible of the surge trigger (Benn and Evans, 2010). Besides, the lubrication of the bed, the deformation of the subglacial sediments (Björnson, 1998), are linked to the subglacial cavity network (Benn and Evans, 2010).

The analyzed features and landform systems associated have allowed us to establish a working hypothesis on the fast flow or surge dynamic glaciers during the LIA. Fast flow processes affected at least 17 LIA glacier complexes, which could be either synchronous or in different stages. These surges modified the preexisting moraines, which means a maximum advances but not necessarily more volume of ice. The main aims of this work are (1) to show how many moraine complexes have landforms related to fast flow glaciers; (2) to understand 
what happened in the LIA morainic complexes during the surges and when did it happen; (3) to characterize the extent that LIA recorded in relation to previous and current ice extents; and finally (4) to interpret the meaning (hydrological, climatic, morphologic...) of this behavior, which has been scarcely studied in small mountain glaciers of temperate regions.

\section{The LIA in the Pyrenees: a review of glacier stages}

During the LIA glaciers were developed in the Pyrenees in more than 19 different massifs (Table 2) and at least 111 cirques have been featured by LIA glaciers, with moraine complexes related to cirque glaciers and very reduced or absent tongues (González-Trueba et al., 2008). The temperature decrease affected mainly the highest mountains, and largely to the Northern faces, showing the relative marginality of the glacial processes during the LIA. The largest cold areas in the Iberian Peninsula are located in the north- and south-face of the high Pyrenees, where temperature went down to create a new landscape and changes in the hydrology, geomorphological processes (periglacial, glacial, torrential) and ecosystems. The maximum reconstructed surface of a single glacier corresponds to the Aneto glacier with 236 ha (González-Trueba et al., 2008), but the Pyrenean glaciers extent reached more than 2700 ha in 1850 (Schrader, 1936). The drop of temperature implied a decline of the Equilibrium Line Altitude (ELA) and the glacial advance. The study of the Pyrenean ELAs, the Medium Equilibrium Line Altitude (MELAS) and temperatures estimations in several massifs (Serrano, 1991, 1998; Lampre, 1994, 1998; Chueca et al., 1998a, 1998b; López Moreno, 2000) have allowed to approach the environmental conditions during the LIA. In the maximum extension of glaciers, MELAs have been estimated between 2620 and $2945 \mathrm{~m}$, depending on the massif and aspect. The range of local ELAs is wide and each massif has notorious asymmetry between northern and southern faces. If in the Western massifs as Balaitous and Infierno the MELAs are located at $2650 \mathrm{~m}$ a.s.l., influenced by oceanic climate and higher altitudes, in Maladeta or Posets massifs, where the continental conditions are dominant, the MELA altitude is located around $2900 \mathrm{~m}$ a.s.l. The temperature decline have been estimated in several massifs, showing fluctuations and variations between about $0.7-0.75^{\circ} \mathrm{C}$ in Maladeta and Infierno-Panticosa, or temperatures $0.9^{\circ} \mathrm{C}$ lower then present day in other massifs coinciding with the $0.92^{\circ} \mathrm{C}$ temperature decline in all Pyrenees (Serrano, 1996, 1998; Lampre, 1994, 1998; Chueca et al., 1998; López Moreno, 2000; Serrano et al., 2002).

LIA glaciers in the Pyrenees advanced and retreated significantly during several phases and they are witnesses of climate variations during the last 500 years. Different authors -by means of diverse techniques- have estimated the historical maximum in several dates. In the Maladeta massif by lichenometry, 1600-1620 (Julián and Chueca, 1998), René (2011) pointed the age of 1820-1830 to the formation of the big moraines, in contact with glaciers until 18301850 and after 1850 a definitive glacier retreat. By dendrochronolgy and morphostratigraphy the LIA maximum has been established between the 17-18th centuries (Creus, 1991; Copons and Bordonau, 1994, 1997; Saz and Creus, 2001). The last one is accepted as the maximum extension in the Alpine glaciers (Le Roy Ladurie, 2004, 2006), during the Maunder Minimum (1645-1700 AD), and we consider that the historical maximum extent of glaciers in the Pyrenees could have occurred between 1680 and $1750 \mathrm{AD}$, period characterised by cold and wet conditions (Oliva et al., 2018). 
Table 2. Synthesis on LIA features in the Pyrenees (modified from González Trueba et al., 2008).

\begin{tabular}{|c|c|c|c|c|c|}
\hline Massif & $\begin{array}{l}\text { Altitude } \\
\text { Summits } \\
\text { m }\end{array}$ & $\begin{array}{l}\text { Cirques } \\
\text { with LIA } \\
\text { glaciers } \\
\text { features }\end{array}$ & Or. & LIA Glaciers & $\begin{array}{l}\text { Present day } \\
\text { Glacier }^{1}\end{array}$ \\
\hline Balaitous & 3144 & 12 & $\mathrm{~N}$ & $\begin{array}{l}\text { Las Néous, Pabat, Arraille, } \\
\text { Batcrabére, Frondellas. }\end{array}$ & Las Néous \\
\hline Panticosa & 3082 & $>14$ & $\mathrm{~N}$ & $\begin{array}{l}\text { Infierno W, Infierno E, Punta } \\
\text { Zarra. }\end{array}$ & Infierno \\
\hline Tendeñera & 2853 & 3 & $\mathrm{~N}$ & Sabocos, Tendeñera, & \\
\hline Vignemale & 3298 & 6 & $\mathrm{~N}, \mathrm{~S}$ & $\begin{array}{l}\text { Gaube, Petit Vignemale, } \\
\text { Oulettes Gaube Montferrat, } \\
\text { Clot de la Hount, Tapou- } \\
\text { Montferrat, Cervillona. }\end{array}$ & $\begin{array}{l}\text { Ossoue } \\
\text { Oulettes de } \\
\text { Gaube } \\
\text { Petit } \\
\text { Vignemale }\end{array}$ \\
\hline $\begin{array}{l}\text { Mt.Perdido- } \\
\text { Marboré }\end{array}$ & 3355 & 15 & $\mathrm{~N}, \mathrm{~S}$ & Epaule, Cascade, Marboré & \begin{tabular}{|l} 
Monte Perdido \\
Gabietous \\
Taillón
\end{tabular} \\
\hline La Munia & 3133 & 7 & $\mathrm{~N}$ & Munia, Barroude. & Munia \\
\hline Neouvielle & 3192 & 2 & $\mathrm{~N}$ & $\begin{array}{l}\text { Maniportet, Tourrat, Pays } \\
\text { Baché }\end{array}$ & \\
\hline Posets & 3375 & 5 & $\begin{array}{l}\text { N,NE } \\
\text { NW }\end{array}$ & $\begin{array}{l}\text { La Paul, Bardamina, Posets, } \\
\text { Llardaneta. }\end{array}$ & \begin{tabular}{|l|} 
Llardana \\
La Paúl \\
\end{tabular} \\
\hline $\begin{array}{l}\text { Gourg Blancs- } \\
\text { Perdiguero }\end{array}$ & 3222 & 16 & $\mathrm{~N}, \mathrm{~S}$ & \begin{tabular}{|l} 
Perdiguero, Literola, \\
Spijeoles, Belloc, Poucherges, \\
Cabrioules, Maupás, Graoués.
\end{tabular} & \begin{tabular}{|l} 
Seil de la \\
Baque \\
Boum \\
Portillon d'Oo \\
\end{tabular} \\
\hline Maladeta & 3404 & 25 & $\mathrm{~N}, \mathrm{~S}$ & $\begin{array}{l}\text { Aneto, Maladeta, Coronas, } \\
\text { Alba, Barrancs, Tempestades. }\end{array}$ & $\begin{array}{l}\text { Aneto } \\
\text { Maladeta } \\
\text { Barrancs } \\
\text { Tempestades } \\
\end{array}$ \\
\hline Others massifs & -- & $<13$ & $\mathrm{~N}$ & $\begin{array}{l}\text { Castillo de Acher, Cambalés, } \\
\text { Ardiden, Culfreda-Batua, } \\
\text { Bachimala, Besiberri, } \\
\text { Cotiella, Mont Vallier. }\end{array}$ & Mont Vallier \\
\hline
\end{tabular}

1. From Rico et al., 2017

The historical sources, lichenometry, dendrochronology and morphoestratigraphy techniques have permitted to establish different glacier LIA stages related to glacial dynamics as a response to climate fluctuations (Nicolás, 1981; Martínez de Pisón and Arenillas, 1988; Serrano and Martínez de Pisón, 1994; Copons and Bordonau, 1994; Lampre, 1998; Creus 1991; Serrano, 1988; 1991, 1996; Chueca and Julián, 1998; Chueca et al., 1998, 2003; Mateo and Gómez Ortiz, 1998, 2000, 2004; Saz and Creus, 2001; Serrano et al., 2002; Grove, 2004; Martín, 2004, 2006; López-Moreno, 2000; González-Trueba et al., 2008; García-Ruiz et al., 2015; Marti et al., 2015). A sequence of 7 morphogenetical stages for the Pyrenees was established (GonzálezTrueba et al., 2008). The LIA glacier maximum (1) is represented by the external frontal and lateral moraines that permit to rebuilt glaciers shorter than $2 \mathrm{~km}$, mainly shorter than $1 \mathrm{~km}$ and without tongues. A retreat and small readvances (2) occurred between 
1750 and 1800 , building numerous but small moraines as a response to minor cool phases at the end of 18th century and the beginning of the 19th (Creus, 1991; Saz and Creus, 2001; Mateo and Gómez Ortiz, 2004), but Ramond de Carbonnières in 1797 still describes the Monte Perdido glacier reaching the "edge of the lake" (Ramond, 1802), an extent similar to the LIA maximum. A glacial advance (3) implied a fast but short growth of glacier when most of the glacier fronts were located close to the frontal moraines at the beginning of the XIX century as it is point out by pyreneists that explored and mapped the Pyrenees. F. Schrader, A. Lequeutre, A. de Franqueville, P.L. Michelier, H. Russell or E. Viollet le Duc supported with texts and maps the extent of glaciers with areas similar to the maximum, although glaciers were thinner (Schrader, 1936). This stage is linked to cold period generated by the Dalton Minimum of solar activity and the volcanic eruptions.

LIA glaciers advance have been dated in Maladeta in 1820-1830 (Julián and Chueca, 1998), in Andorra in 1805-1829 (Mateo and Gómez-Ortiz, 2004) and Monte Perdido in 1790-1830 (García-Ruiz et al., 2015). Historical sources permit us to locate the maximum previous to 1830 in the Maladeta Glacier. Finally, the melting of the ice begins during the stage of glacial recession (4), when glaciers are separated from the moraine around the 70s of the 19th century, as was recorded by the contemporary observers (Vallot, Shrader, Trutat). The temperature increased since the middle of the 19th century steered a very strike glacial retreat (Chueca et al., 2008). Minor readvances and glacier equilibrium (5) occur during the last decades of the 19th century, with a common advance around 1890, until the twenties of the 20th century, after the LIA has finished. Later, glaciers retreat accelerated with small and intermittent advances in some glaciers, as Oulettes of Gaube with short progress in 1945 and 1964 (Grove and Gellatly, 1995; René, 2013), until the drastic retreat with sudden lost of mass, as response to strong disequilibrium with current climate conditions (Chueca et al., 2007; López-Moreno et al., 2016), interrupted only by small equilibrium periods at the end of the 70's and 80's (Martínez de Pisón and Arenillas, 1988; Martínez de Pisón et al., 1995; Grove and Gellatly, 1995; René, 2001, 2003, 2013), before the disappearance of the most LIA glaciers and the conservation of only 19 glaciers in 2016 (Rico et al., 2017).

\section{Methodology}

This work is based on the glacier landsystem analysis and on the study of morphosquences and characteristic landform systems following the methodology described by Boulton and Eyles (1979), Evans et al.(1999), Benn et al. (2003), Evans and Rea (2003), Benn and Evans (2010). By fieldwork and photo interpretation we have detected flutes and push and hummocky moraines in 17 places with geomorphological traces of fast ice flow. We have selected 8 for being the most representative (Fig. 1). The used database for the geomorphological cartography is coming from fieldworks, aerial photography and digital elevation models (DEM) from the IGN (National Geographical Institute) with $5 \mathrm{~m}$ resolution. We have analyzed cirques and moraine complexes where flutes and front moraines have been detected, interpreting and classifying by genesis. The moraines, which point 
out the LIA glacier extent and retreat stages, were mapped on the field and by color orthophotos of Spanish and French Geographical National Institutes, and color aerial photos of the ERHIN Programme (1996). From the fieldworks and aerial photos we made the interpretation according to the distribution of landforms and the linkages between the different GVL and SGL sectors to establish differentiated dynamic environments (Sharp, 1985; Evans and Rea, 1999, 2003; Farnworths et al., 2016).

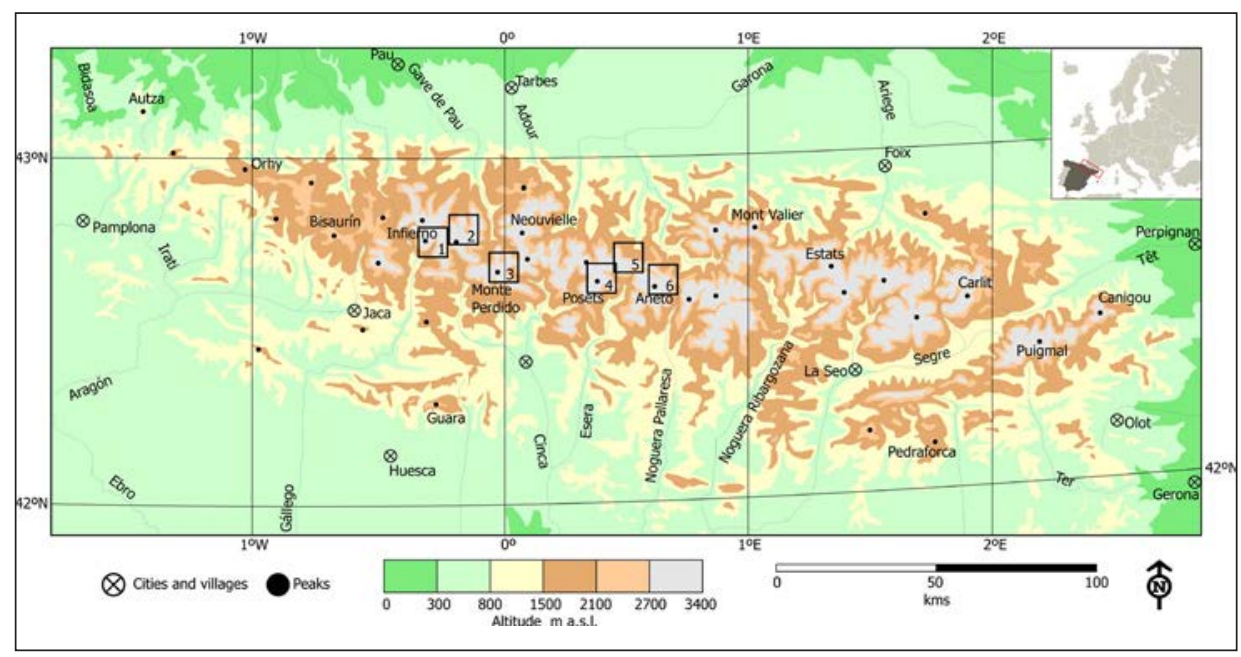

Figure 1. Location in the Pyrenees of massifs where LIA moraine complexes have been studied. 1, Infierno massifs, Eastern and Western Infierno moraine complexes. 2, Vignemale massif, Oulettes de Gaube moraine complex. 3, Monte Perdido massif, Monte Perdido and Marboré moraine complexes. 4, Posets massif, La Paúl moraine complex. 5, Literola moraine complex. 6 , Maladeta massif, Tempestades moraine complex.

The height, distances, slopes and orientation of the flutes are obtained from the aerial photos and cartography. The results were compared with the fieldwork observations. We have cartographied the main landforms features from the studied mountain cirques, distinguishing the characteristic morphosquences of each area. We have establish in each morainic complex the morphosquences based on the morphostratigraphy (Lukas, 2006; Hughes, 2007, 2010), which in such as recent and well-preserved moraines allows a very accurate spatial and chronology relationships. Flutes are very useful not only to know about the glacier size and morphology, but also to establish the morphogenetic stages. In this way, we can correlate the different types of geomorphologies and reconstruct the evolution of the glaciers during the LIA and its possible connection with environmental changes. Finally, from the LIA data and climatic reconstructions from previous investigations on the Iberian Peninsula and Southern France (Creus et al., 1996; Barriendos, 1997; Saz and Creus, 2001; Saz, 2003; Le Roy Ladurie, 2004, 2006; Le Roy Ladurie et al., 2011; Liñán et al., 2012; Alberola, 2014; Luterbacher et al., 2016; Tejedor et al., 2016, 2017; Oliva 
et al., 2018), we have reconstructed the different cooling periods and variations in humidity in relation with the glacier evolution, creating a hypothesis about the response of the LIA glaciers to the short time changes in temperature and moisture during the 19th century.

\section{Results on the LIA glacial landsystems and moraine complexes in the Pyrenees}

There are 17 glacier cirques with flutes and associated push moraine systems in the Pyrenees. All of them are found in the highest mountains of the Central Pyrenees $>3000 \mathrm{~m}$, that show complex moraine systems (with ground, lateral and terminal moraines), and which still there are eight actives glaciers (Table 3). Eight of the moraine systems show morphosquences with flutes and frontal moraines, identifiable as GVL or SGL, which we have studied in detail.

Table 3. Cirques with flutes detected on morainic complexes in the Pyrenees.

\begin{tabular}{|c|c|c|c|c|c|c|c|}
\hline $\mathbf{N}^{\mathbf{o}}$ & Glacier & Or. & $\begin{array}{l}\text { Alt. m } \\
\text { a.s.l. }\end{array}$ & $\operatorname{Rock}^{1}$ & Basin $^{2}$ & Climate $^{3}$ & $\begin{array}{l}\text { Present } \\
\text { day ice }^{4}\end{array}$ \\
\hline 1 & Infierno Occ & $\mathrm{N}$ & 3081 & $S$ & $S$ & OT & Gl \\
\hline 2 & Infierno Or & $\mathrm{N}$ & 3076 & $S$ & $S$ & OT & Ip \\
\hline 3 & Oulettes de Gaube & $\mathrm{N}$ & 3299 & $\mathrm{~L}, \mathrm{~S}$ & $\mathrm{~N}$ & $\mathrm{O}$ & Gl \\
\hline 4 & Monte Perdido & $\mathrm{N}$ & 3325 & $\mathrm{~L}, \mathrm{Sd}$ & $S$ & M & Gl \\
\hline 5 & Marboré & NNE & 3251 & $\mathrm{Sd}, \mathrm{L}$ & $\mathrm{S}$ & M & Ip \\
\hline 6 & La Paúl & NNE & 3321 & $\mathrm{~S}$ & $S$ & $\mathrm{CM}$ & $\mathrm{G}$ \\
\hline 7 & Literola & $\mathrm{S}$ & 3107 & $\mathrm{G}$ & $S$ & $\mathrm{CM}$ & - \\
\hline 8 & Tempestades & NNE & 3345 & $\mathrm{G}$ & $S$ & $\mathrm{CM}$ & $\mathrm{G}$ \\
\hline 9 & Barrancs & NNE & 3404 & $\mathrm{G}$ & $S$ & $\mathrm{CM}$ & $\mathrm{G}$ \\
\hline 10 & Las Neous & $\mathrm{N}$ & 3146 & $\mathrm{G}$ & $\mathrm{N}$ & $\mathrm{O}$ & $\mathrm{G}$ \\
\hline 11 & Gourg Blancs & $\mathrm{N}$ & 3064 & $\mathrm{G}$ & $\mathrm{N}$ & $\mathrm{CM}$ & Ip \\
\hline 12 & Cabrioules & $\mathrm{N}$ & 3107 & $\mathrm{G}$ & $\mathrm{N}$ & $\mathrm{CM}$ & Ip \\
\hline 13 & Maupas & $\mathrm{N}$ & 3111 & G & $\mathrm{N}$ & $\mathrm{CM}$ & Ip \\
\hline 14 & Bugarret & & 3038 & $\mathrm{G}$ & $\mathrm{N}$ & $\mathrm{CO}$ & Ip \\
\hline 15 & Aneto & $\mathrm{N}$ & 3354 & G & $\mathrm{S}$ & $\mathrm{CM}$ & G \\
\hline 16 & Perdiguero & $\mathrm{NE}$ & 3219 & $\mathrm{G}$ & $S$ & $\mathrm{CM}$ & - \\
\hline 17 & Coronas & SW & 3404 & $\mathrm{G}$ & $\mathrm{S}$ & $\mathrm{CM}$ & - \\
\hline
\end{tabular}

1. S, shales. L, limestone. Sd, sandstone. G, granite. 2. S, Southern basin. N, Northern basin. 3. OT oceanic transition. O, oceanic. M, Mediterranean. MT, Mediterranean transition. CM, Mediterranean continental. 4. Gl, glacier. Ip, Ice patch.

The studied moraine systems indicate a predominance of the Northern orientation (88\%), while the most developed flutes are found in the only cirque with Southern orientation. The locations are also Southern dominant (88\%), with a predominance of the Mediterranean environments (62.5\%), over the Atlantic ones 
$(37.5 \%)$. The lithology is not significant, with equitable presence of shales, limestone and sandstones, and granitic rocks, neither the altitude, climate nor lithology with the presence of flutes (Table 4). The most important variables in the presence of flutes are the altitude, the concentration in the Pyrenean Southern faces and the Mediterranean environments.

Table 4. Flutes-moraines system in the LIA Pyrenean moraine complexes.

\begin{tabular}{|c|c|c|c|c|c|c|c|c|c|}
\hline \multirow{3}{*}{$\begin{array}{l}\text { LIA complex } \\
\text { (U3) }\end{array}$} & \multicolumn{4}{|c|}{$\begin{array}{r}\text { Flutes } \\
\end{array}$} & \multicolumn{3}{|c|}{ Frontal moraines } & \multirow{3}{*}{$\begin{array}{c}\text { Total } \\
\begin{array}{c}\text { Uneveness } \\
\mathbf{m}\end{array} \\
\end{array}$} & \multirow{3}{*}{ Rock } \\
\hline & \multicolumn{2}{|c|}{ Altitude, $m$} & \multirow{2}{*}{$\begin{array}{c}\text { Lenght } \\
\mathrm{m}\end{array}$} & \multirow{2}{*}{ Type $^{1}$} & \multicolumn{2}{|c|}{ Altitude, m } & \multirow{2}{*}{\begin{tabular}{|c|c|}
$\begin{array}{c}\text { Lenght } \\
\text { m }\end{array}$ \\
\end{tabular}} & & \\
\hline & $\max$ & $\min$ & & & $\max$ & $\min$ & & & \\
\hline Infierno Occ & 2630 & 2550 & 210 & PS F & 2575 & 2570 & 25 & 80 & Shales \\
\hline Infierno Or & 2820 & 2750 & 175 & PS & 2790 & 2740 & $20-30$ & 80 & Shales \\
\hline $\begin{array}{l}\text { Oulettes de } \\
\text { Gaube }\end{array}$ & 2350 & 2200 & 520 & PS & 2200 & 2200 & 40 & 150 & Limestone \\
\hline Monte Perdido & 2520 & 2450 & 520 & PS F & 2440 & 2450 & 120 & 110 & Limestone \\
\hline Marboré & 2800 & 2760 & 100 & PS & 2760 & 2760 & 90 & 40 & Limestone \\
\hline La Paúl & 2780 & 2700 & 200 & PS & 2680 & 2700 & 75 & 100 & $\begin{array}{l}\text { Shale, } \\
\text { granite }\end{array}$ \\
\hline Literola & 2845 & 2790 & 220 & PS & -- & -- & -- & 55 & Granite \\
\hline Tempestades & 2680 & 2470 & 250 & PS F & 2550 & 2470 & 25 & 210 & Granite \\
\hline
\end{tabular}

1. PS, parallel-side flutes. PSF, parallel side flutes and like-fan directions.

\subsection{The Central Infierno LIA complex}

The Northern Infierno cirques show significant erosional and depositional glacial features (Russell, 1908; Barrère, 1956; Martínez de Pisón and Arenillas, 1988; Serrano and Agudo, 1988; Serrano, 1991, 1998) with a complex moraine system at $2580 \mathrm{~m}$ a.s.1. (Fig. 2). This one is composed by a frontal moraine system formed at least by 4 minor arcs (U1), a maximum advance with the ELA at $2725 \pm 25 \mathrm{~m}$ a.s.l. (Serrano, 1994). After a recession with minor pulsations, a more voluminous lateral moraines is formed (U2), and a complex formed by little push and hummocky moraines linking with flutes (U3) indicate an advance until the frontal moraine. Finally a recent minor pulsation built minor arcs up valley deteriorated by melt water and fluvioglacial recovering (U4) (Figs. 3 and 4D). There are not data from the historical evolution, except of the work by A. Leqeutre that described in 1874 that he reached the glacier walking through the moraine. Additionally, in the map from Schrader (1887) the glacier is already towards the morainic complex. Therefore, is in the 70 s of the 19th century when the ice started the retreat and thinning, separating from the push moraine system, and the flutes surfaced.

The push and hummocky moraines seem as little arcs without continuity and low elevation, formed by very heterometric boulders linking to the flutes. Flutes are parallelsided showing an expansion movement in the front. Flutes have been formed down 
valley from the last glacial rock-bar on a ramp of $20^{\circ}$ slope scattered by marble boulder on a till formed mainly by shales. They are conserved between 2560 y $2630 \mathrm{~m}$ a.s.l. and occupy $210 \mathrm{~m}$ length.

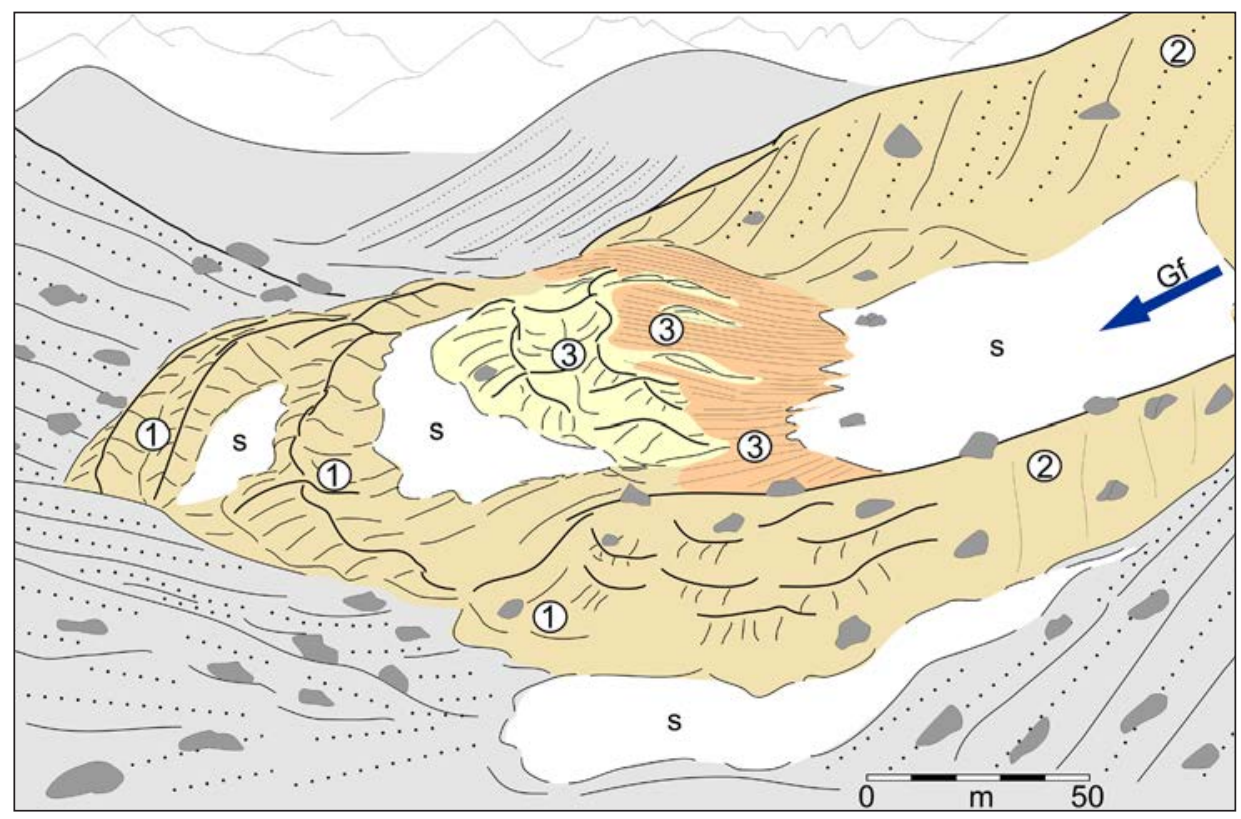

Figure 2. View of the LIA frontal moraine system of Western Infierno. 1, External frontal moraines (U1). 2, Lateral moraines (U2). 3. Moraine complex with flutes and little push moraines (U3). S, snow patches. Gf, direction of glacial flow.

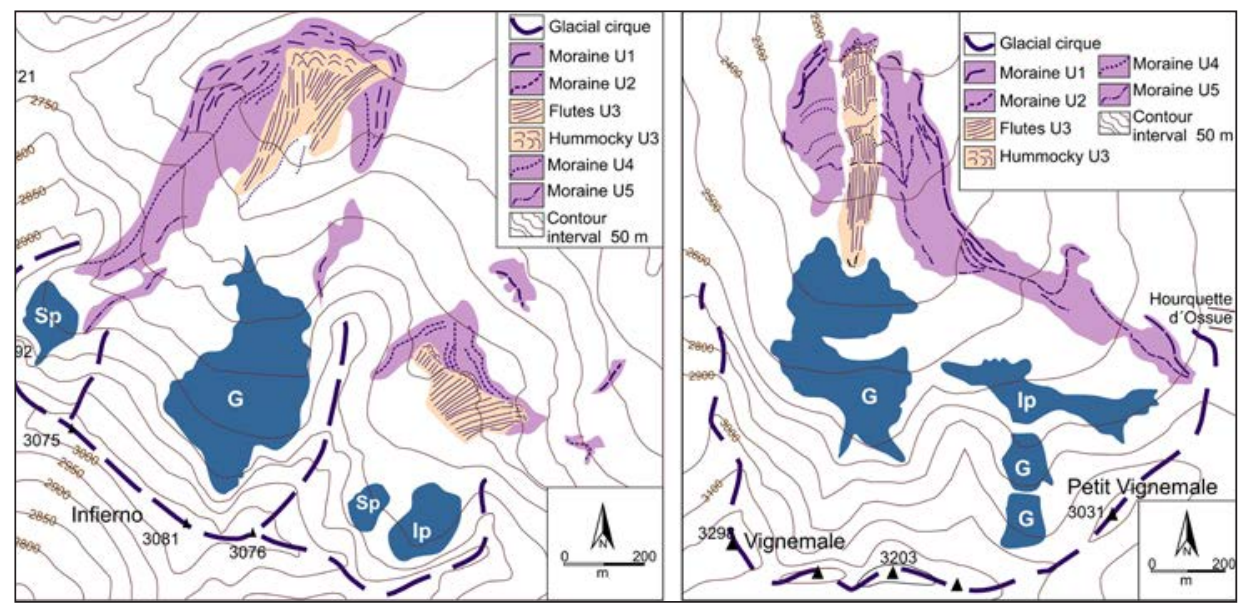

Figure 3. Glacio-geomorphological sketch of Infierno (left) and Oulettes de Gaube (Vignemale massif) (right). G: glacier; Ip: ice patch; Sp: snow patch. 


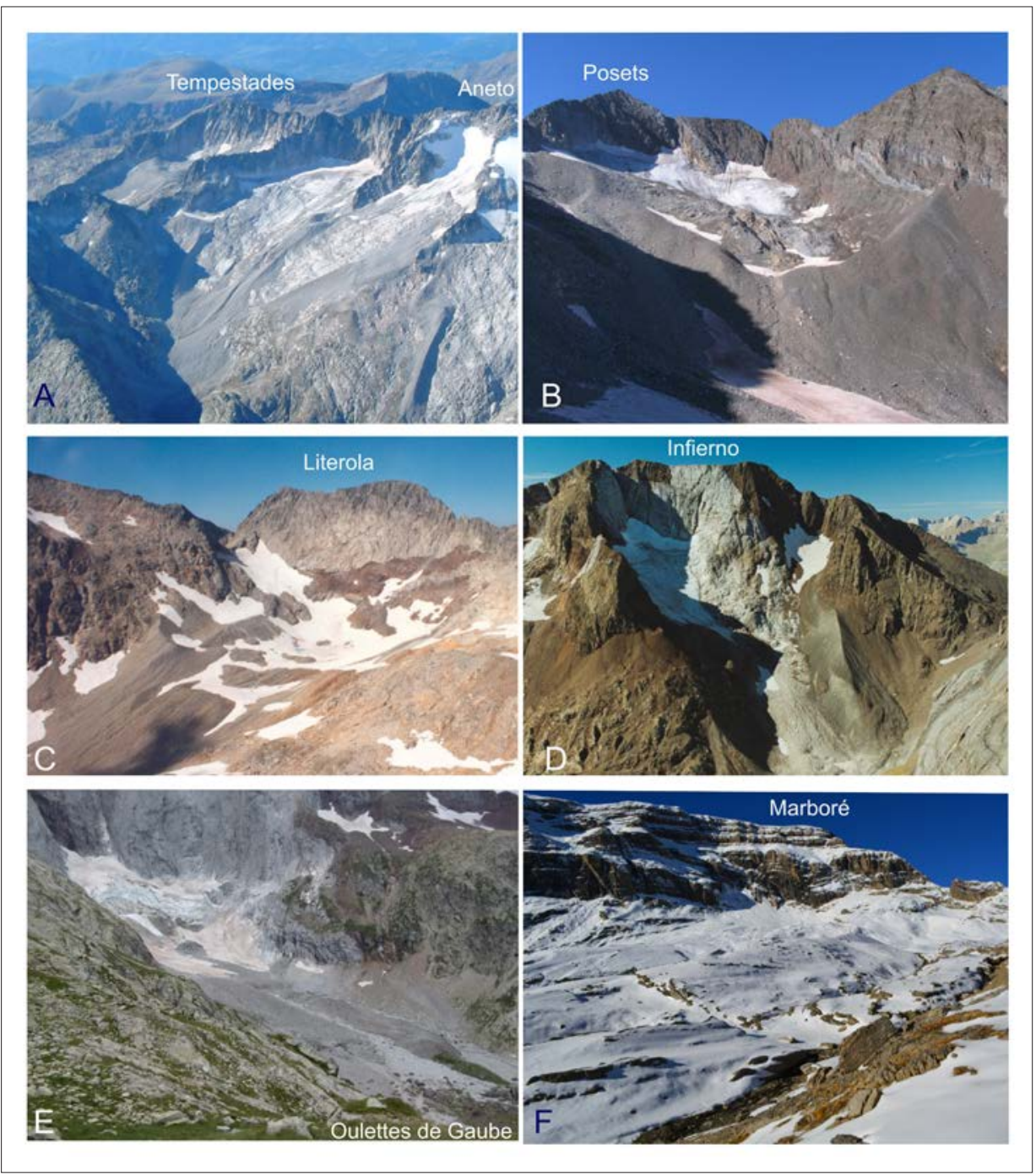

Figure 4. Cirques and LIA moraine complexes studied. A: Tempestades, Maladeta massif. B: La

Paúl, Posets massif. C: Literola (picture by Eduardo Martínez de Pisón). D: Western glacier, Infierno massif (picture by Eduardo Martínez de Pisón). E: Oulettes de Gaube, Vignemale massif. F: Tucarroya cirque, Monte Perdido-Marboré massif.

\subsection{The Eastern Infierno LIA complex}

The cirque shows two morainic complexes, separated by a glacial rock bar, mapped previously by Barrère (1953), Martínez de Pisón and Arenillas (1988) and Serrano (1988, 1991, 1998). The external moraines (Fig. 3) are located at $2640 \mathrm{~m}$ a.s.l., formed by a disturbed frontal moraine (U1) during the maximum advance. After a recession 
of, at least, $150 \mathrm{~m}$ up-valley from the previous moraines, a second complex consists on greater moraines together with minor arcs (U2). Again, a small recession in the inner part of the moraine complex resulted in a group of small push and hummocky moraines linking with flutes (U3). Flutes show parallel erosion lines of between 50 and $160 \mathrm{~m}$ length; they developed in a counterslope on the moraine complex of $26.5^{\circ}$ slope. Finally, a clear glacial recession until nowadays has occurred. As in the Central Infierno complex, Schrader represented, in the Central Pyrenees map (edited in 1887), the glacier near the moraines, so the beginning of the U3 retreated is before that date.

\subsection{The Oulettes de Gaube LIA complex}

Located in the Vignemale Massif under the big north face, a 400 high wall and the Couloir de Gaube feeding the cirque with avalanches. The glacial retreat after the LIA has been studied, showing important thinning and recession of glaciers of Ossue and Oulettes de Gaube, the first one losing more than $1.5 \mathrm{~km}$ length and $200 \mathrm{~m}$ of altitude in 60 years (Russell, 1908; Grove and Gellatly, 1995; Grove, 2004; René, 2001, 2003, 2011, 2013). The second one underwent the same progression from the 18th when historical records have permitted to date the maximum advance (Grove and Gellatlty, 1995).

The Oulettes cirque has an important LIA complex, formed when the glacier reached $1.5 \mathrm{~km}$ length, located the front at $2160 \mathrm{~m}$ a.s.1., and the ice was $120 \mathrm{~m}$ thick in the central sector (Figs. 3 and 4E). The morainic complex shows the most external moraines as lateral, because the frontal portion has been eroded by proglacial water. The external lateral moraine indicates an important expansion period forming the larger moraines (U1), correlated with the LIA maximum extent and completed by small recession arcs on the moraine slopes (U1). After an important recession a second lower lateral moraine (U2) was built, pointing out the new extent but with significant lower thickness than during the previous advance. An advance and equilibrium stage reached alike length that in the previous phase but the ice mass was thinner; after a new recession up valley, other advance deformed the till and built pushed moraines lined on the external moraines and flutes (U3) that occupy only the central portion of the glacier. Finally a succession of seven minor arcs crossing all moraine deposits (U4) have been dated between 1890 and 1997 (René, 2013), corresponding to the post-LIA recession. This glacier can be wider in extent, but the subglacial erosional power affected only to a narrow fringe of less than $100 \mathrm{~m}$ width. Finally, the transversal ridges crossing all U3 correspond with a short equilibrium phase estimated by René (2011) using historical maps and photographs, mainly belonging to 20th century, during 1888-1892, 1915-1920, 1940-1945, 1965-1980 and the last one in 1996-1998. The last one is separated only around 30-50 meters from the glacier, which have retreated $475 \mathrm{~m}$ during the last 160 years (46\% lost), with quick recessions (1850-1885, 1894-1904, 1945-1950, 1992-1995) and equilibrium (René, 2011, 2013), although the flutes have been conserved during all the ice melting episode.

The push moraines occupy a narrow portion in contact with the external moraine $(2200 \mathrm{~m})$, no more than $40 \mathrm{~m}$ length, but the flutes are extended until $2350 \mathrm{~m}$ in a ramp of $17^{\circ}$ slope. Intermittent and one direction parallel-side flutes go down until the frontal moraine. They are crossed by small, metric thickness frontal moraines, attributed to 
stabilization microstades (René, 2011). Their small size, position and relation with flutes (Fig. 5B), permit to be interpreted as small push moraines deforming the till, originated by supraglacial debris, but also as crevasses-squeeze ridges generated subglacially during the recession phases.

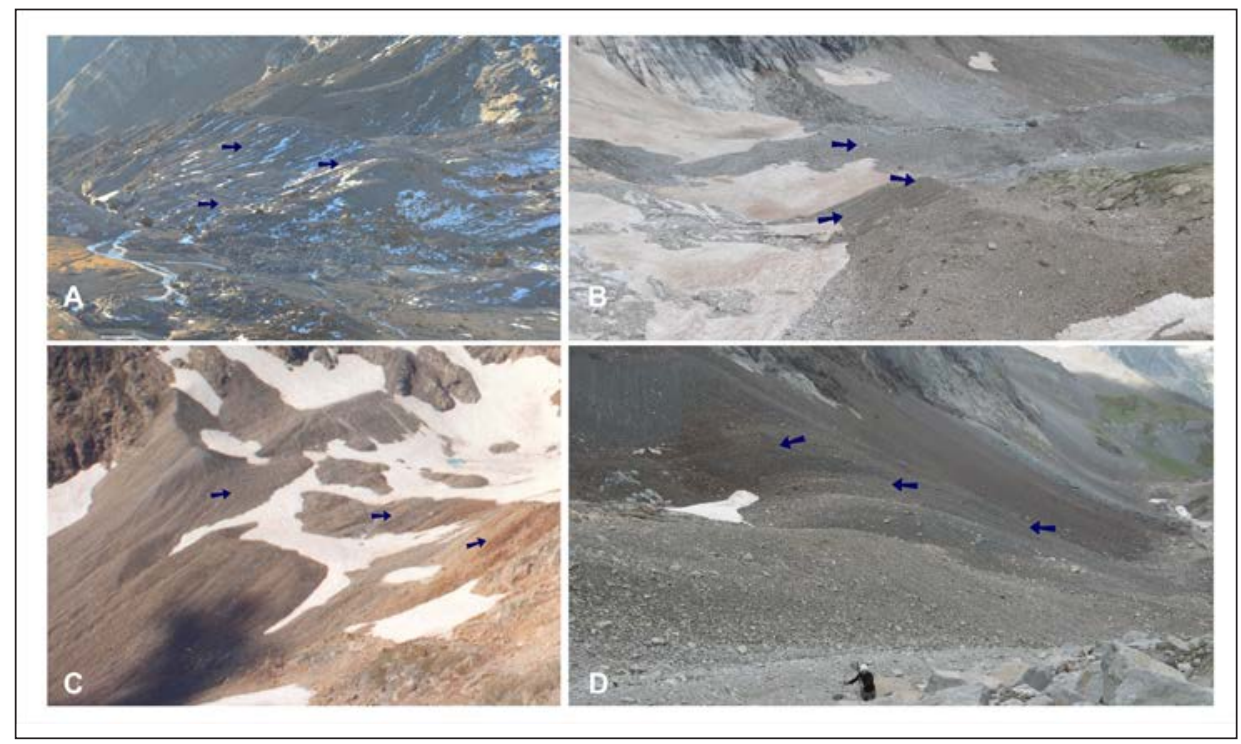

Figure 5. LIA moraine complexes with flutes. A: Monte Perdido. B: Oulettes de Gaube, Vignemale massif. C: Literola (picture by Eduardo Martínez de Pisón). D: La Paúl, Posets massif. Arrows point out the flutes on moraines.

The abundance of historical sources (maps, drawings, pictures, studies, alpinists descriptions) helps to date the moraines. According to "Les cartes d'État Major, $1: 80,000$ " (edited in 1852), the glacier front was around $2200 \mathrm{~m}$ a.s.1., placing U3 next to external frontal moraines (U2) or right behind them (Grove and Gellatly, 1995; Grove, 2004; René, 2011). Before 1850 there was an advance prior to the general retreat that occurred between 1850 and 1885. This advance affected U2 and deposited U3, resulting in a modification of the former moraines and flutes along the complex. The retreat was fast, so that by 1887 the ice had retreated $320 \mathrm{~m}\left(\sim 9 \mathrm{~m} \mathrm{yr}^{-1}\right)$. The first pictures from 1887 show flutes over the U2 moraines. René (2011) notes the moraine formation in 1820-1830, just before the thinning of the ice that occurred between 1830 and 1850, and the moraine separation from 1850. Therefore, the glacier advance that deformed the subglacial till could be dated before 1850 (18201840 ?), but after the advance responsible of $\mathrm{U} 2$.

\subsection{The Monte Perdido LIA complex}

Monte Perdido (3348 m a.sl.) is the third highest peak in the Pyrenees. On its North face the fourth largest glacier of the Pyrenees is located, as well as and 
an important LIA moraine complex (Fig. 6). From the first climb by Ramond de Carbornnières, the glacier and moraines have been studied in detail (Ramond, 1802; Tonnellé -in 1858- 1977; Schrader -in 1854- 1936; Gaurier -from 1900 to 19091921; Gómez de Llarena, 1936; Hernández Pacheco and Vidal Box, 1946; Boyé, 1952; Martínez de Pisón and Arenillas, 1988; Nicolás, 1981, 1986; Ferrer et al., 2003; García-Ruiz and Martí-Bono, 2001; Martín-Moreno, 2004, 2006; García-Ruiz et al., 2014; López-Moreno et al., 2016), and mapped and pictured by Schrader, Beck, Trutat, Briet or Gaurier.

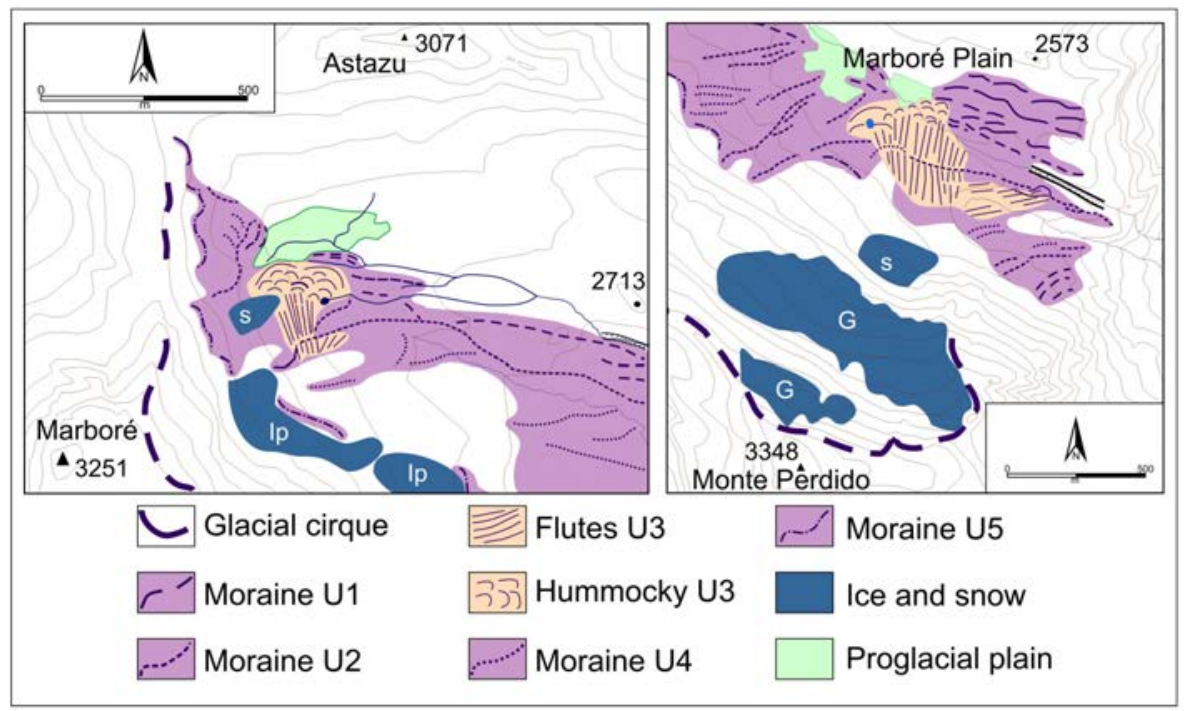

Figure 6. Glacio-geomorphological sketch of Monte Perdido (right) and Marboré (left). G: Glacier; S: snow; Ip: ice patch.

The Northern Monte Perdido cirque has a moraine complex attributed to several phases from Younger Dryas to LIA (Nicolás, 1981, 1986; Martín-Moreno, 2004, 2006; García-Ruiz et al., 2014). The LIA complex is formed by 4 units, the external reaching $2470 \mathrm{~m}$ a.s.l., and is composed of front-lateral moraines (U1) because the ice flows to the east towards the Pineta Valley (Upper Cinca Valley). The second one is formed by a big lateral moraine (U2) formed when the glacier turned east toward Pineta, dividing the floor of the valley between the glaciated area, in the South side, and deglaciated in the north side, with a proglacial creek from the Cilindro and Marboré glaciers. The U2 and the till cover appears deformed and eroded, forming flutes and push moraines (U3) overcoming U2 and reaching U1. Upslope minor arcs point the location of the glacier during the XX century, when a big icefall descended from the north face of the Monte Perdido Peak.

Flutes mainly define the U3 (Fig. 5A). They are parallel-sided with two flow directions, ENE and N, from $2520 \mathrm{~m}$ a.s.l. to $2450 \mathrm{~m}$ a.s.l. toward ENE, and 
$2512 \mathrm{~m}$ a.s.l. toward the north. Both have low gradient: only $13^{\circ}$ and $2.9^{\circ}$, respectively. It is clear by the flutes directions that they modified both sides of the moraine, overcoming the arc in the west part and generating small new push moraines on the moraine ridge. The ice pushed till on the U1, and slided over the moraine through the external side, where possibly deposited covered ice and hummocky structures. A picture of Trutat dated form 1896 shows a glacier ice portion recovered by debris in a hummocky topography with ice and lagoons. It is interpreted as debris covered stagnating surge snout affected by outwash channels from the Cilindro and Marboré glaciers.

The historical documents allow us to date the glacier during the LIA. Ramond (1802) placed the Monte Perdido glacier near the current Tucarroya Lake in 1797. This was an exaggerated description, as Schrader (1898) noted, although the ice still formed a single body from Cilindro and Monte Perdido. Schrader described in 1874 this single glacier, although it appeared divided into two ice masses by 1914; however, it is difficult to know if this was due to new interpretations or new observations. The description of Ramond (1802) may be correlated with the U1, i.e. the maximum extent of the LIA, and the Schrader description of 1874 with the U2, or from the 1914 text with the U3, when the glacier was close to the U2, although clearly thinner (Schrader, 1936). The first pictures from 1884 showed that the ice had already retreated respect to U2 and U3, partly surfacing the flutes, but very close $(\sim 50 \mathrm{~m})$ to $\mathrm{U} 2$, which means that the glacier before $1884 \mathrm{had}$ advanced over $\mathrm{U} 2$ and after that it had thinned and retreated $250 \mathrm{~m}$ approximately. Although we do not know the U2 chronology, it is located between the retreat after 1797 and the U3 advance (right after the map from Schrader), which place U2 between the mid 18th century and the beginning of the 19th century. During this period, between $\mathrm{U} 2$ and $\mathrm{U} 3$, the retreat was around 5-7 $\mathrm{m} \mathrm{yr}^{-1}$. Ten years later (1892), the ice stayed in a similar place, and in 1896 still dead-ice and stagnantice topographies persisted in the bottom of the valley, although two years later (1898) the glacier show supraglacial debris and a thinner front with well preserved flutes in the proglacial area. Thus, a fast retreat occurred from before 1880 and 1890 , with the ice mass thinning and dead ice at the front, remaining at the same position until the 40 s of the 20 th century. To sum up, the ice of the Monte Perdido glacier has retreated from the largest moraines (U2) in the 70s of the 19th century, which means that the advance that created the flutes, the push moraines and likehummocky topography must be previous and thus must have happened earlier than 1850 .

\subsection{The Marboré LIA complex}

In the Monte Perdido-Marboré massif there are 15 cirques shaped by LIA glaciers, but the most relevant locates in the north face of the Monte Perdido, Cilindro and Marboré peaks. In the Western extreme of the large TucarroyaMarboré cirque, the LIA complex of the Marboré glacier is located between 2780 and $2870 \mathrm{~m}$ a.s.l., connecting today with the Marboré ice patch underneath the more than $300 \mathrm{~m}$ high walls. 
The LIA complex (Figs. 4F and 6) is formed by an external moraine system of small lateral ones (U1) located at $2780 \mathrm{~m}$ a.s.l., and a long and voluminous lateral moraine (U2) located between 2670 and $2830 \mathrm{~m}$ a.s.l. A glacier of ca. $1.5 \mathrm{~km}$ joined the Cilindro and Monte Perdido glacier, occupying the southern sector of the Tucarroya cirque. Between U1 and U2 a moraine complex is developed, formed by push and hummocky moraines with a chaotic topography where it is possible differentiate several discontinuous and overimposed arcs (U3). Up slope they connect with flutes (U3) shaped on the lateral moraine and eroded in the upper part. During this phase, the main tongue of the Marboré glacier went down to the ENE, but a small ice flow exceed the lateral moraine and went down by the other side, forming the flutedhummocky-pushed system.

The flutes are parallel-sided, $100 \mathrm{~m}$ length, oriented to the north, between 2770 and $2800 \mathrm{~m}$ a.s.1. Flutes occupy the external slope of the lateral moraine, with a gradient of $17^{\circ}$, and are composed of till. They have continuity with the moraine complex, formed by big boulders in hollows and arcs that have been interpreted as a possible rock glacier (García-Ruiz et al., 2014; Ventura, 2016). We interpret the discontinuous and poorly defined morainic arcs, with a chaotic topography and linked with the flutes, as a possible fast flow from the main Marbore glacier. The map from Schrader (edited in 1874), the only historical record, represents a very imprecise glacier limits (U2). The map from 1914 (E.1/20,000) shows the glacier extending over the entire morainic complex, so it is quite difficult to make reconstructions from these cartographies.

\subsection{La Paúl LIA complex}

La Paúl cirque is located in the north face of the Posets peak (3369 m), the second highest massif in the Pyrenees, below a $250 \mathrm{~m}$ height shale wall. The LIA glacier evolution has been analyzed through mapping and dynamic studies on moraines and rock glaciers (Alonso et al., 1983; Martínez de Pisón and Arenillas, 1988; Serrano et al., 2002, 2009, 2011; Lugon et al., 2004). During the maximum LIA advance the ELA has been estimated at $2825 \mathrm{~m}$ a.s.1. in La Paul (Serrano et al., 2002), and three main units have been differentiated (Figs. 4B and 7). An external moraine complex formed by lateral and frontal moraines (U1) divided into two arcs in the frontal portion. The glacier eroded La Paúl rock glacier and incorporated material (ice and debris possibly) from the rock glacier to the moraines. After an important ice recession of $250 \mathrm{~m}$, a new and voluminous moraine arc (U2) was deposited at $2780 \mathrm{~m}$. After the equilibrium period and a new recession, the glacier advanced and eroded the moraine arcs, forming flutes on the moraines (U3) in counterslope and going down toward the U1 (Fig. 5C). A new chaotic push moraine formed by debris recovering ice with discontinuous arcs and hummocky topography (U3) is located on U1. Still in 2001 buried dead ice appeared between the LIA debris in the frontal complex (Lugon et al., 2004; Delaloyé, 2004). Above the flutes, in the inner of the U2 complex, the last equilibrium period placed at $2790 \mathrm{~m}$ a.s.1., scattered till in lee-side of the roches mutonneés on a granitic rock- 
bar, and small moraines with two little arcs (U4). It was the last equilibrium stage before the continuous recession of ice from $\mathrm{U} 4$ until the present day.

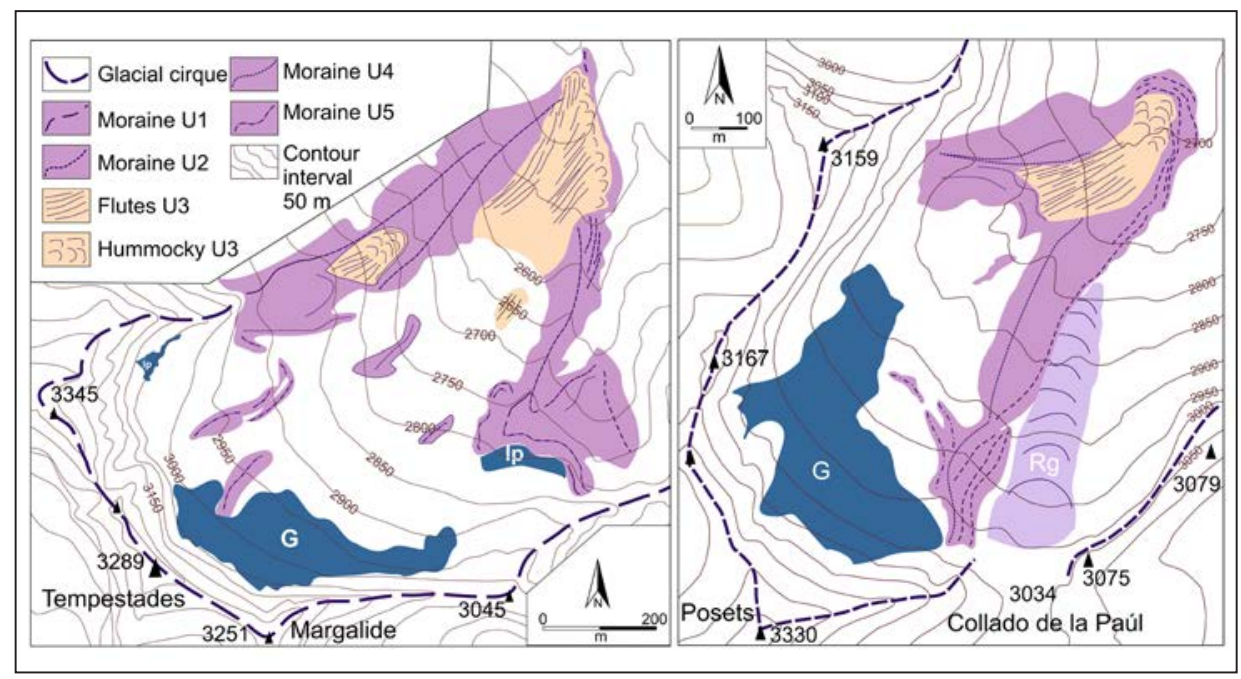

Figure 7. Glacio-geomorphological sketch of Tempestades (Maladeta massif) (left) and La Paúl (Posets massif) (right). G: glacier; Ip: Ice patch.

There are no documents on La Paúl valley and glacier until the 20th century (around the 1920s) when the ice was located next to the U4 and the visible till in the picture is today partially missing by postglacial erosion.

Flutes developed between 2780 and $2700 \mathrm{~m}$, in the frontal portion of the glacier showing an advance limited to a narrow fringe that reshaped the upper moraines. Flutes surpassed the counterslope of the moraine and fell on a slope of $21^{\circ}$ where the parallel-side flutes occur. This is the last important advance of the La Paul Glacier. Retreat between the 1950s of the 19th century and 1920s of the 20th century have been estimated around $4.7 \mathrm{~m} \mathrm{yr}^{-1}$.

\subsection{The Literola LIA complex}

The Literola LIA cirque is small but shows a complex evolution (Figs. 4C and 5C). According to Martínez de Pisón et al. (1995) there are 3 moraine arcs: (U1) an external moraine well developed, which belongs to the LIA glacier maximum; (U2) simple front moraines, inside the LIA maximum, attributable to retreat positions; and (U3) a recent and single front moraine. Our works (Martín-Moreno, 2004; González-Trueba et al., 2008) and fieldwork observations show a more complex model, where there are up to 4 frontal moraine sequences, some with flutes. Here, the flutes are more defined in the internal part of the moraines and over subglacial 
sediments. These flutes finalize suddenly in the mean external moraine (U1), which means that the ice advance could not surpass the LIA maximum.

\subsection{The Tempestades LIA complex}

The Tempestades cirque is located in the Maladeta granitic massif, the highest of the Pyrenees, to the East of Aneto peak. A high crest between the highest peak (3345 m), Tempestades (3289 m) and Salenques (2932 m), forms a cirque on the headwalls of the Barrancs valley where the frontal LIA moraines are located at $2470 \mathrm{~m}$ a.s.1. (Fig. 4A). The strong unevenness of $775 \mathrm{~m}$ and the gradient permit to reach a low point by means of a very steep glacier that not shaped an overdeepened basin and rock bar landforms. Therefore, the LIA glacier had 50-60 m thickness in the middle point and a very steep tongue of approximately $700 \mathrm{~m}$ length. LIA landforms and moraine (Fig. 7) have been studied in parallel to the other cirques of the massif, such as the Aneto cirque (4 moraine arcs), Maladeta cirque (three moraine arcs) or Coronas cirque (two moraine arcs). In total, sixteen cirque glaciers with LIA features have been analysed (Martínez de Pisón and Arenillas, 1988; Copons and Bordonau, 1994; Lampre, 1998; Chueca et al., 2005; González-Trueba et al., 2008). Copons and Bordonau (1994) established a maximum advance with three small periods located at the beginning of the 18th century and a second one at around 1820 with a continuous retreat until current times. In the Aneto cirque Chueca et al. (2005) pointed out three phases of glacial stabilization (1820-30 to 1857 ; $1914-20$ to $1934-35 ; 1957$ to 1981 ), and two fast glacial recession, the first one between 1857 to 1901-04, and the second one between 1981 and 2000. Pictures and gravures of Maladeta glacier (Fig. 8) show that in 1833 the glacier was in contact with the most voluminous frontal and lateral moraines in 1833 , but 24 years later (1857) the ice was separated and 73 year later (1901) clearly separated more than one hundred meters and the ice thinned several tens of meters. As Schrader said, in the second half of 19 th century the ice was close to the moraines although it was thinned.

In the Tempestades cirque 4 main units have been differentiated (Fig. 7, left): the external moraine complex formed by a small arc in the frontal portion (U1) and possibility by small lateral arcs. Upslope of the previous moraines and mounted on them, two voluminous lateral moraines (U2) between 2450 and $2750 \mathrm{~m}$ a.s.1. draw the LIA glacier. After an important recession of at least $400 \mathrm{~m}$, the glacier advance eroded the frontal moraine arcs (U2), forming flutes and chaotic push moraine (U4) next to the U1 moraine. The frontal push and chaotic moraines are located between 2470 and $2550 \mathrm{~m}$ a.s.1. in a narrow area less than 25 meters. Between 2470 and 2680 parallel-side flutes developed showing two flow directions, $\mathrm{N}$ and NE, and the opening of a fan-like of the ice flow in the frontal section of the glacier. The flutes are divided forming small groups at 2650 and $2750 \mathrm{~m}$ a.s.l. (those of the north side limiting the Barrancs glacier lateral moraine). In the lowest sector a continuous, $250 \mathrm{~m}$ length flutes system developed linking with the outermost moraines. Upslope of the flutes there are small arcs (U4) showing two small ancient tongues of the Tempestades LIA glacier. 

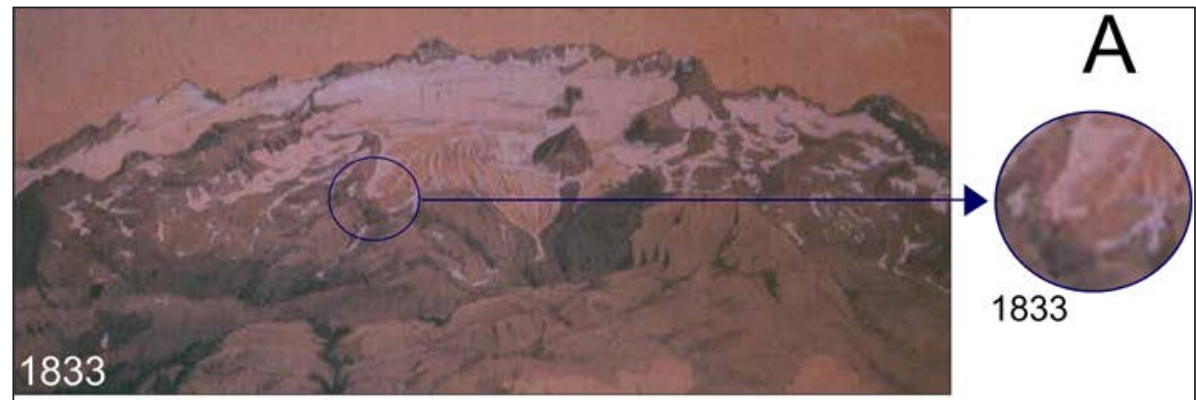

1833
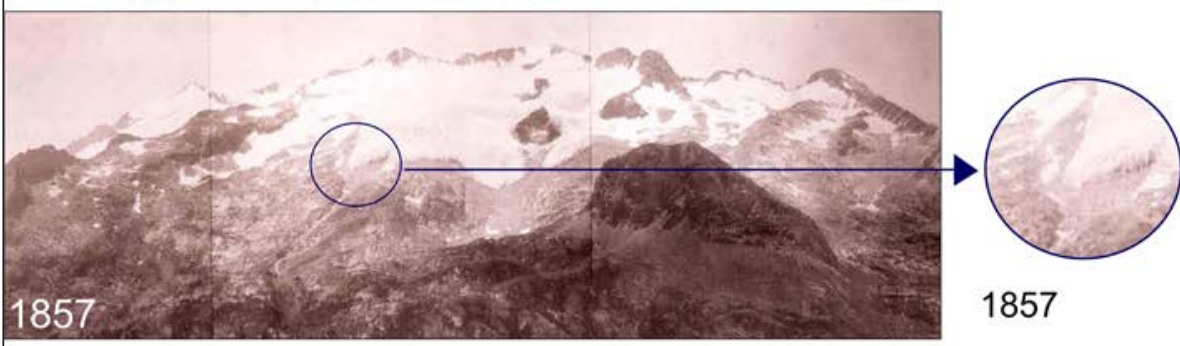

1857
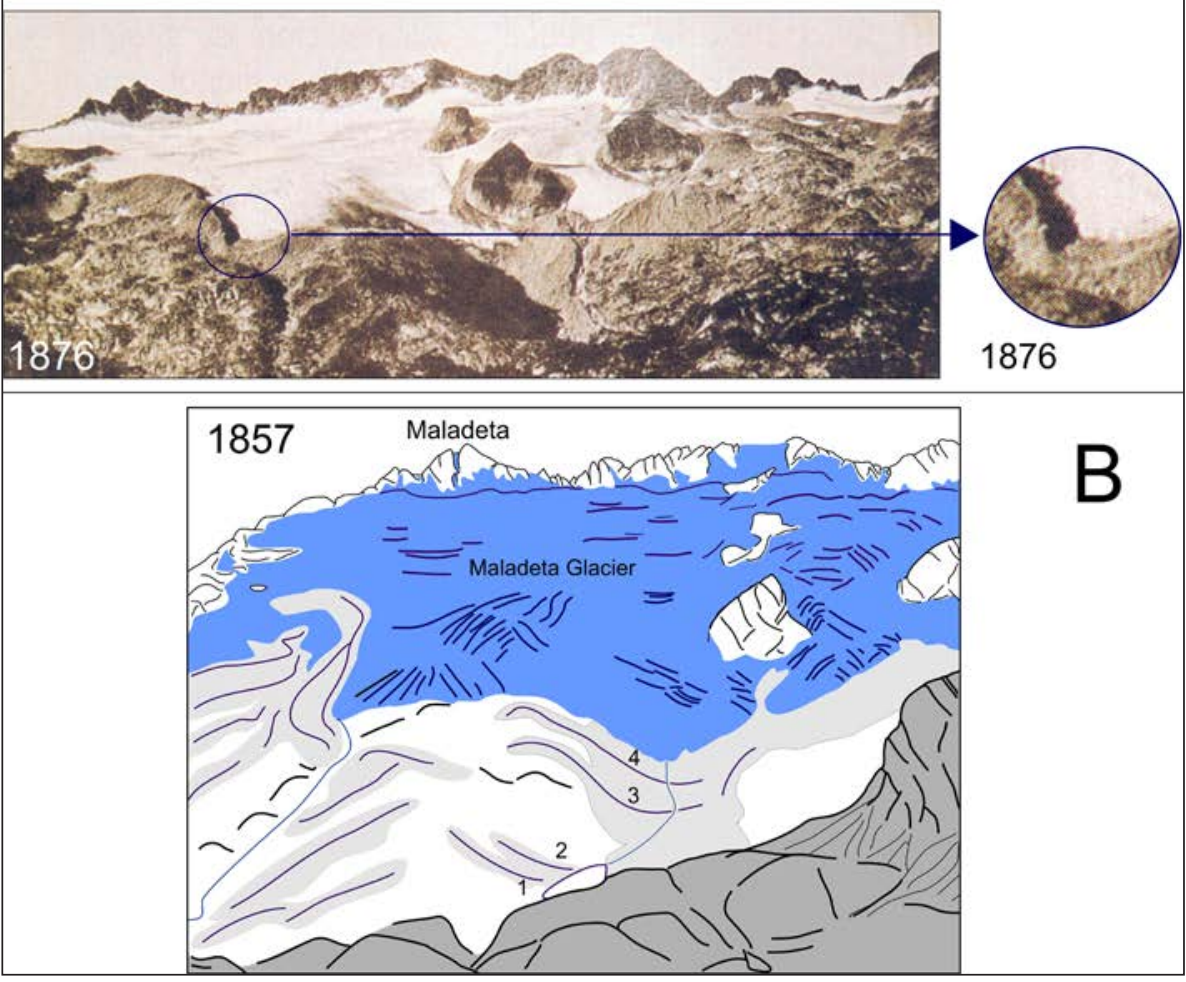

B

Figure 8. A: Pictures showing the position of the ice related to the LIA moraines in Maladeta glacier during the 19th century. 1833 pictured by E. Violet le Duc, 1857 pictured by Aimé Civiale, and 1876 pictured by Ch. Fabre, all modified. B: Interpretative drawing of A. Civiale picture (1857) where it is possible to observe the moraine sequence with several retreat arches from 1 to 4. 
Documents of the year 1876 on the Tempestades glacier show the ice separated of the U2 moraines, consistent with the Maladeta images, and the flutes structures partially free in the lower sector, with a long tongue around of $400 \mathrm{~m}$ length (Fig. 9). A design of André Slomszynski drawn previously to 1909 (published in 1920) show a small tongue of two hundred meters length. An estimated retreat of $\sim 5.5 \mathrm{~m} \mathrm{a}^{-1}$ between 1876 and 1909 coincides with the fast glacial recession pointed by Chueca et al. (2005). An initial recession between 1830 , when the ice was in contact with the moraines in the Maladeta cirque, and 1876 shows an average retreat of approximately $2.8 \mathrm{~m} \mathrm{a}^{-1}$ while in the 20th century (1905-2002) the medium retreat was around $6.4 \mathrm{~m} \mathrm{a}^{-1}$, and $13.8 \mathrm{~m} \mathrm{a}^{-1}$ during the last decades (2002-2015).

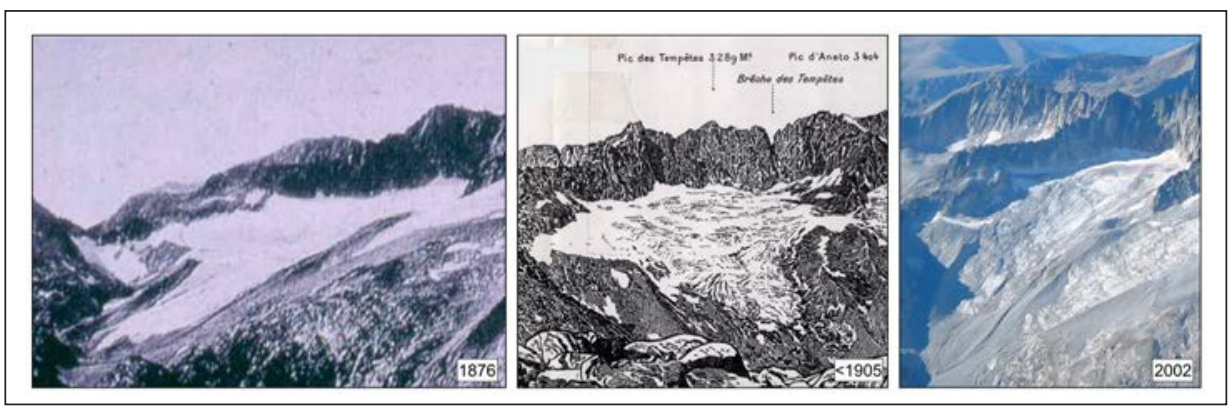

Figure 9. The Tempestades glacier (Maladeta massif) post-LIA retreat. 1876, pictured by Ch. Fabre (modified from Annuarie Club Alpine Française), 1905 by André Slomszynski, and 2002 by Eduardo Martínez de Pisón. It can be observed the fast retreat occurred during the last quarter of the 19th century $\left(5.5 \mathrm{~m} \mathrm{a}^{-1}\right)$, enhanced during the next decades until today.

\section{Discussion on LIA glaciers advances}

\subsection{Fast flow processes and chronologies in the Pyrenean LIA moraine complexes}

Six of the studied moraine complexes show a morphostratigraphic sequence defined by the succession of several meters length flutes, and small size frontal push moraines. Benn et al. (2003) propose that in some margins of temperate glaciers subglacial moraines with imbricate thrust and flutes may create, although only the crevasses-squeeze ridges are related with surge processes, as we have observed in the Oulettes de Gaube glacier. But the succession of landforms and sediments may also be used to detect terrestrial SGL (Brynjólfsson et al., 2014; Farnsworth et al., 2016). In that case, the formation of well developed parallel-side flutes and the associated push moraines indicate fast flow of ice.

The morphosequences described in the Pyrenees, characterized by the deformation of the till, the superimposed flutes and small hummocks, are interpreted as GVL, rare and associated to the margins of temperate glaciers (Benn et al., 2003; Benn and Evans, 2003), but SGL as well. In that case, it is common the succession of push moraines, the deformation of the pre-surges sediments, gradual transition to a patchy hummocky moraines, and low amplitude flute with crevasse-squeezed ridges and subglacial till (Evans et al., 1999, 2007, 2009; Evans and Rea, 1999, 2003). Despite the last two elements, there are successions in the U3 of Infierno, Oulettes de Gaube, Monte Perdido, Marboré, La Paúl and Tempestades 
cirques, all of them formed in temperate environments and with small dimensions compared with the Arctic GVL and SGL. The presence of landforms and deposits, just like that the sequences described above, confirms the fast flows of ice in the studied glaciers, related with surge dynamics. Glacier surges in alpine environments, either in oceanic and continental environments, as the recent surges in the Belvedere glacier, Monte Rosa (Haeberli et al., 2002) or the subsequent advances during the LIA in Vernagtferner, Austria (Hoinkes, 1969), combined with the described morphosquences, support the hypothesis of the fast flow of ice or surges during the LIA in the Pyrenees.

The maximum glacial advance during the LIA has been established for the 18th century in Oulettes de Gaube, Monte Perdido and Maladeta (Copons and Bordonau, 1994; Grove and Gellatlty, 1995; García-Ruiz et al., 2014). While the description made by Ramond (1802) only permits to know that the ice in Tucarroya had a large thickness prior to 1797, in Maladeta massif Copons and Bordonau (1994) established the maximum advance at the beginning of the 18th century with several subsequent minor equilibrium stages. Therefore, we can establish that the external moraines (U1) are previous to 19th century, probably formed during the 18th century.

More difficult is to establish the age of U2. It was formed posterior to the maximum, dated at the early 18th century, and before the U3 advance because this unit is superimposed to and deformed the U2. Pyreneists of the 19th century described glaciers next to the larger moraines of LIA (U2), but after 1850, and very well known by maps, gravures and pictures, the separation between the moraines (U2) and the thinning ice occurred. As U3 advance is previous to the E. Violet le Duc design (1833), when the Maladeta glacier contacted the U2, les Cartes d'État Major (1852), the A. Civiale picture (1857), the F. Schrader map (1874) or undoubtedly the Ch. Fabre (1876) and L. Briet (1887) pictures, the U2 should be deposited between mid-18th and early 19th centuries. So, the first pictures in Tempestades (1876) and Monte Perdido (1887) show the flutes free of ice, pointing out quick recession. In Aneto and Oulettes de Gaube, Chueca et al. (2005) and René (2011) have been established a glacial stabilization between 1820 and 1830, before a glacier thinning between 1830 and 1850 in Oulettes de Gaube.

Studies and documents indicate that a glacier advance previous to the glacial recession occurred between 1850 and 1885, pointed in Oulettes de Gaube, where the glacier was located next to U2 or overimposed in Monte Perdido, Infierno and Maladeta (Cartes d'État Major, 1852; Grove and Gellatly, 1995; Grove, 2004; René, 2011). The advance modifies deposits and landforms of U2 and generates flutes and push moraines (U3). So, we can date the glacial advance deforming the subglacial till as earlier as 1850 and later than 1820 if we accept the age of U2 between the late 18th century and 1820-1830 decades. Before 1850 there was a small advance followed by a continuous recession until the 1920 s of 20 th century, which is considered the post-LIA recession.

We can deduce that the ice advance generating the U3 landsystem is the last advance during the LIA, developed for a period of 20-35 years as fast flows or surge glaciers and the subsequent melting, all of them between the 1920s and 1940s of the 19th century. So, 
it is consistent with the Schrader and pyreneists views, with glaciers slightly separated from U2 moraines and thinned.

\subsection{Environmental and climate significance of LIA fast flows in the Pyrenees}

The presence of fast flow glacier dynamics or surges in the Pyrenees coinciding with the end of the LIA -after the most important glacier advance and equilibrium of this cooling period-, lead us to think in a glacier response to environmental changes, more than endoglacial behaviors or individual responses to the deglaciation. The glaciers react to environmental factors, such as winter precipitation and summer temperatures, making thus possible to link the morphostratigraphy of the LIA moraine complexes with the historical climatic evolution.

During the LIA the colder conditions in the Iberian Peninsula occurred from 1300 to 1850 (Oliva et al., 2018) with several warmer and colder periods caused by natural events, mainly associated to solar forcing and volcanic activity. Although there is no an agreement on the timing of the transition between the Medieval Climate Optimum and LIA, the 14th century is generally accepted as the begining of the LIA. In the Iberian Peninsula and SW Europe, the LIA began with a moderate cooling together with an increasing climate variability from 1300 to 1480 . Afterwards, relatively warmer conditions and less frequent extreme events were recorded until 1570 (Jones and Mann, 2004; Barriendos and Rodrigo, 2006; Oliva et al., 2018). From 1570 to 1620 a gradual climate cooling was recorded while glaciers grew in the highest mountains of Europe to finally reach the maximal extent by the middle 17th century (Le Roy Ladurie, 2004). Nevertheless, the coldest climate conditions occurred between 1620 and 1715, during the Maunder Minimum, when cold and droughts took place in all Southern Europe. In fact, during that interval the coldest decade of the millennium (1691-1700) was recorded (Jones et al., 1998; Luterbacher et al., 2016). During this climate period, in the Iberian Peninsula cold and very dry conditions have been observed, with temperatures ca. $1^{\circ} \mathrm{C}$ lower than around 1850 , in average, and ca. $2^{\circ} \mathrm{C}$ lower than present-day values (Domínguez-Castro et al., 2010; Oliva et al., 2018). U1 in the studied LIA moraine complexes have been correlated to the begining of 18 th century.

After the late 17th and early 18th century cooling, a warmer and relatively stable period (1715-1760), when glaciers in the western Alps retreated (Nussbaumber and Zumbühl, 2012) and some glaciers extinted in Sierra Nevada (Oliva and Gómez-Ortiz, 2012), was followed by cold conditions and highly variable climate from 1760 to 1800 . In France, colder temperatures were registered from 1763, with a cold sequence until 1774. Coherently, glaciers in the Alps advanced from 1770, with a seven years lag as response to climatic change observed in all glaciers during the LIA (Le Roy Ladurie, 2006; Le Roy Ladurie et al., 2011). The Laki volcanic eruption (1783-84) contributed to the cooling in the North Hemisphere, afecting Iberia and the Pyrenees (Prohom et al., 2016), and linking with the Dalton Minimum (1790-1820), a cold period that favoured glacial advances during the late 18th century and early 19th century. This time interval was then characterized by cold temperatures and advances in the Pyrenean glaciers until the proximities of previous moraines. In Northern Iberian Peninsula a cold period 
beteween 1630 and 1790 implied a decrease of winter temperatures around $0.25-1.2^{\circ} \mathrm{C}$ and spring temperatures around $0.25-0.5^{\circ} \mathrm{C}(\mathrm{Saz}, 2003$; Tejedor et al., 2016, 2017).

The first half of the 19th century was defined in the Iberian Peninsula by highly variable climate conditions with three periods (Oliva et al., 2018):

(i) Relative stability phase (1800-1815). It was a period of stability coinciding with the Dalton Minimum until that a new volcanic eruption, the Tambora one (1815), implied a global cooling of ca. $0.5^{\circ} \mathrm{C}$ (Fischer et al., 2007; Auchmann et al., 2012). In the Iberian Peninsula summer temperatures were $2-3^{\circ} \mathrm{C}$ colder (Trigo et al., 2009) and the glacier response in the Pyrenees was observed as an important advance, shaping the bigger moraines of the LIA (U2) and reaching the maximum extent during the first decades of the 19th century. During the next years, between 1818 and 1821, a maximum advance in the alpine glaciers was registered (Mer de Glace, Argentière, Bossons, Grindewald). Glaciers grew until the 1860 decade when the glacial recession in the Alps began (Rhone, Grindewald, Aletch) (Nussbaumber et al., 2007; Zumbühl et al., 2008; Nussbaumber and Zumbühl, 2012). However, in the Pyrenees we have not accurate data on the maximum extent, although we know that glacier recession began before 1833 or 1857 in the Maladeta, 1852 in Oulettes de Gaube and 1874 in Monte Perdido. Along this period the flutes were shaped, the main moraines (U2) were correlated with advances produced during the late 18th and early 19th centuries, until posTambora ice growth ca. 1820-1830 decades, according to the Chueca et al. (2005) and René (2011) chronologies in Aneto and Oulettes de Gaube LIA moraine complexes. After this period, Pyrenean glaciers could start a general recession only interrupted by a short fast flow located between 1820-1830 and 1850, when glaciers advanced again.

(ii) Phase of extreme events (1815-1835): It was characterised in Europe by alternating warm and dry summers $(1818,1822,1825,1826)$, hot summers (1827-1831) and cold ones (1829-1830), but mainly from 1827 weather was rainy, with a "Wet five-year" (1827-1832) period (Le Roy Ladurie, 2006). Climate conditions in the Iberian Peninsula were characterized by a very cold period (associated to the Dalton Minimum 1810-1838) that was also very humid (1810-1821) and with summer temperatures, between $2-3^{\circ} \mathrm{C}$ colder (Saz, 2003; Trigo et al., 2009). All these characteristics implied a potential good snow accumulation in the Pyrenean glaciers.

(iii) Phase of slight warming trend with intense hydrometeorological events (18351850): It is defined by a cool sequence with fresh summers, spring-summer temperatures $0.4^{\circ} \mathrm{C}$ lower, and extremly cold winters $(1838,1841,1845,1847)$, representing a cool and wet period between 1838 and 1839 (Le Roy Ladurie, 2006). So, the $1837-1845$ period was characterised by cool summers and wet and cold winters with abundant snowfalls, all of them causing glacier advances in the Alps, peaking in 1855 (Le Roy Ladurie et al., 2011; Brönnimann, 2015). Humid and cold winters (1815-1835) and cool summers (1835-1850) were favorable to glacier advances, resulting in fast ice flows and surges. 
Surges are related with humid mountain environments (Western Alps, South Alaska, Yukon, British Columbia, Iceland), but also with continental ones (Central Alps, Caucasus, Tien Shan, Tibet and Pamir-Karakorum) and the Arctic (Greenland, Novaya Zembla, Svalbard). The relationships between surges and climate are not well understood since, for example, the hydrological changes that produce the surges are unknown (Eisen et al., 2001; Sevestre, 2015; Sevestre and Benn, 2015). However, there are studies that link surges with climatic oscilations (Hoinkes, 1969); the intensification in the surge cycles has been mainly related with an increase in precipitation and a decrease in temperature (Kotliakov, 2009; Striberger et al., 2011). Therefore, continued positive mass balance -and the appearance of water at the glacier base-, destabilizes the ice mass and increases suddenly the velocity due to the lower friction between the glacier and the bed. In cold and thin glaciers, without surging dynamics currently, there are evidences of fast flows from the LIA (Sevestre, 2015).

The formation of flutes requires a great amount of meltwater (Benn and Evans, 2010), which fills the glacier drainage system, saturates the bed and enhances the glacier basal sliding (Björnson, 1998). The subglacial erosion over the soft-bedded sediments by melt water saturation deforms the subglacial deposits with flutes over the till and moraines, forming push moraines and hummocky morphologies. In that context, the fast ice flows from the 1830s and 1850s in the Pyrenees could be a response to the cool summers and the increase of snow precipitation during the 1820s. The small size of these glaciers could mean a faster response than in the Alps, for example. The abundant meltwater during the cool summers in a temperate mountain such as the Pyrenees, where there is abundant solar radiation, could have causes that the Pyrenean glaciers saturated their drainage system producing fast flows of ice due to the basal sliding, resulting in the deformation of the basal and frontal saturated sediments. In the short period of 20-30 years, at the end of the LIA (around 1850), in a context of general retreat but with the last cooling and precipitation increase, at least 17 glaciers responded with fast flow or surging that modified the morainic complexes in flutes, push moraines and hummocky moraines. Shortly after, a fast retreat and ice melting of between 4 and $9 \mathrm{~m} \mathrm{a}^{-1}$ began, stretching and thinning the ice mass. The mountaineers from the 19th century described extensive but thin glaciers, which reached the U2 complexes, and rapidly retreated far away from the main moraines. The existence of fast flow features in at least $14 \%$ of Pyrenean glaciers, and the fact that they are grouped in a short time of 30-40 years, is an indicator of a possible response to the regional or global environmental conditions.

\section{Conclusions}

We have found fast flow stages or surging during the LIA in the Pyrenees. The flutes occur over till, basal and lateral moraines, in slopes between $15-25^{\circ}$ and counterslopes, and push moraines with an ice core, conserved until the end of the 19th century (at least until 1870). The glacial fast flow processes eroded and modified the U2 moraines by pushing over the saturated sediments. These processes were associated in all of the studied glaciers with the period between 1820 and 1840, at the end of the LIA, just before the main post-LIA deglaciation. The occurrence of fast flow or surges in a period 
of 20-35 years, subsequent to the formation of the LIA moraine, affected more than 17 glaciers in the whole Pyrenees. We related it with a possible climatic response to the changing conditions after the Dalton Minimum and the end of the coldest years of the $1820 \mathrm{~s}$. The sudden cooling and the increase of winter precipitation could produce the environmental conditions -water availability from snow and ice melting during the summer-, to generate hydrodynamic changes in the small glaciers, as a quick response to the new environmental conditions. It can be stated the existence of terrestrial surge glacial landsystem in temperate mountains associated to climatic changes related with the retreat of the small mountain glaciers, analogous to what is happening now in the Belvedere Glacier (Alps).

\section{Acknowledgements}

To the Professor Francisco Alonso Otero, who introduced us the questions regarding the presence of flutes in the Pyrenees decades ago, and motivated this investigation thanks to his observation skills on the field. This research has been funded by I+D+I project CGL2015-68144-R (MINECO of Spanish government-FEDER). We thank the contributions of two referees, Ana Moreno and an anonymous one, whose corrections and suggestions have contributed to improve the manuscript.

\section{References}

Alberola, A. 2014. Los cambios Climáticos. La Pequeña Edad del Hielo en España. Ediciones Cátedra, Madrid.

Alonso, F., Martínez de Pisón, E. 1983. Nota informativa acerca de los trabajos del Instituto Español de Glaciología (INEGLA). Anales de Geografía de la Universidad Complutense 3, 287-289.

Alonso, F., Nicolás, P., Martínez de Pisón, E. 1983. Los glaciares españoles actuales. Madrid, INEGLA, 28 pp., policop.

Auchmann, R., Brönnimann, S., Breda, L., Bühler, M., Spadin, R., Stickler, A. 2012. Extreme climate, not extreme weather: the summer of 1816 in Geneva, Switzerland. Climate of the Past 8, 325-335. http://doi.org/10.7892/boris.17361.

Barrére, P. 1953. Equilibre glaciaire actuel et quaternaire dans l'Ouest des Pyrénées Centrales. Revue Géographique des Pyrénées et du Sud Ouest 2, 116-134. https://doi.org/10.3406/ rgpso.1953.1368.

Barriendos, M., Rodrigo, F.S. 2006. Study on historical flood events of Spanish rivers using documentary data. Hydrological Sciences Journal 51 (5), 765-783. https://doi.org/10.1623/ hysj.51.5.765.

Benn, D.I., Evans, D.J.A. 2010. Glaciers and glaciations. Hodder Education, London.

Benn, D.I., Kirkbride, M.P., Owen, L.A., Brazier, V. 2003. Glaciated valley landsystems. In: D.J.A. Evans (Ed.), Glacial Landsystem. Arnold, London, pp. 372-405.

Björnsson, H. 1998. Hydrological characteristics of the drainage system beneath a surging glacier. Nature 395, 771-774. https://doi.org/10.1038/27384.

Boulton, G.S., Eyles, N.1979. Sedimentation by velley glaciers: a model and genetic classification. In: C. Schluchter (Ed.), Moraines and varves, Balkema, Rotterdam, pp. 121-134.

Boyé, M. 1952. Gélivation et cryoturbation dans le Massif du Mont Perdu (Pyrénées centrales). Pirineos 23, 5-30. 
Briet, L. 1902. Le glacé de Mont-Perdú. Revue Club Alpine Francaise, Secc. Sud-Ouest 1500, 183-186.

Brönnimann, S. 2015. Climate changes since 1700. Springer verlag, London, 359 pp. https://doi. org/10.1007/978-3-319-19042-6.

Brynjólfsson, S., Schomacker, A., Ingólfsson, O. 2014. Geomorphology and the Little Ice Age extent of the Drangajökull ice cap, NW Iceland, with focus on its three surge-type outlets. Geomorphology 213, 292-304. http://doi.org/10.1016/j.geomorph.2014.01.019.

Chueca, J., Julián, A. 1996. Datación de depósitos morrénicos de la Pequeña Edad del Hielo: Macizo de la Maladeta. In: A. Pérez Alberti, P. Martini, W. Chesworth, A. Martínez Cortizas (Eds.). Dinámica y Evolución de Medios Cuaternarios. Public. Xunta de Galicia, A Coruña, pp. 171-182.

Chueca, J., Peña Monné, J.L., Lampre, F., Julián, A. 1998. La Pequeña Edad del Hielo en el Pirineo Central y Meridional. Inferencias paleoambientales a partir de datos geomorfológicos. In: A. Gómez Ortiz, A. Pérez Alberti (Eds.), Las huellas glaciares de las montañas españolas. Serv. Public. Universidade de Santiago, Santiago de Compostela, pp. 307-328.

Chueca, J., Peña, J.L., Lampre, F., García-Ruiz, J.M., Martí, C.E. 1998. Los glaciares del Pirineo aragonés: estudio de su evolución y extensión actual. Dpto. Geografía, Zaragoza.

Chueca, J., Julián, A., Saz, M.A., Creus, J., López-Moreno, I. 2003. El glaciar de La Maladeta (Pirineo central español): análisis de su evolución desde la Pequeña Edad del hielo y su relación con factores climáticos. Cuaternario y Geomorfología 17, 41-55.

Chueca, J., Julián, A., López-Moreno, J.I. 2008. The retreat of the Pyrenean Glaciers (Spain) from the Little Ice Age: data consistency and spatial differences. Terra Glacialis 137-148.

Chueca, J., Julián, A., Saz-Sánchez, M.Á., Creus, J., López-Moreno, J.I. 2005. Responses to climatic changes since the 'Little Ice Age' on Maladeta Glacier (Central Pyrenees). Geomorphology 68, 167-182. https://doi.org/10.1016/j.geomorph.2004.11.012.

Chueca, J., Julián, A., López-Moreno, J.I. 2007. Recent evolution (1981-2005) of the Maladeta glaciers, Pyrenees, Spain: extent and volume losses and their relation with climatic and topographic factors. Journal of Glaciology 53, 547-557. https://doi. org/10.3189/002214307784409342.

Copons, R., Bordonau, J. 1994. La Pequeña Edad del Hielo en el Macizo de la Maladeta (Alta cuenca del Ésera, Pirineos Centrales. In: C. Martí-Bono, J.M. García-Ruiz (Eds.), El glaciarismo surpirenaico: nuevas aportaciones. Geoforma Ediciones, Logroño, pp. 111-124.

Copons, R., Bordonau, J. 1997. El registro glaciar correspondiente a la Pequeña Edad del Hielo en la Península Ibérica. In: J.J. Ibáñez, B.L. Valero, C. Machado (Eds.), El paisaje mediterráneo a través del espacio y del tiempo. Implicaciones para la desertificación. Geoforma Ediciones, Logroño, pp. 295-310.

Creus, J. 1991. Tendencia secular de la temperatura de mayo en el Pirineo central (1302-1989). Notes de Geografía Física 20-21, 41-49.

Delaloyé, R. 2004. Contribution á l'etude du pergélisol de montagne en zone marginale. Geofocus $10,240 \mathrm{pp}$.

Domínguez-Castro, F., García-Herrera, R., Ribera, P., Barriendos, M. 2010. A shift in the spatial pattern of Iberian droughts during the 17th century. Climate of the Past 6, 553-563. https:// doi.org/10.5194/cp-6-553-2010.

Eisen, O., Harrison, W.D., Raymond, C.F. 2001. The surges of variegated glacier, Alaska, USA, and their connection to climate and balance mass. Journal of Glaciology 47, 351-358. https:// doi.org/10.3189/172756501781832179.

Evans, D.J.A. (Ed.) 2003. Glacial Landsystem. Arnold, London.

Evans, D.J.A., Lemmen, D.S., Rea, B.R. 1999. Glacial landsystems of the southwest Laurentide Ice Sheet: modern Icelandic analogues. Journal of Quaternary Science 17, 673-679. 
Evans,D.J.A.,Rea,B.R.1999.Geomorphology and sedimentology of surging glaciers: Alandsystems approach. Annals of Glaciology 28, 75-82. https://doi.org/10.3189/172756499781821823.

Evans, D.J.A., Rea, B.R. 2003. Surging glacier landsystem. In: D.J.A. Evans (Ed.), Glacial Landsystems. Arnold, London, pp. 259-288.

Evans, D.J.A., Twigg, D.R., Rea, B.R., Shand, M. 2007. Surficial geology and geomorphology of the Bruarjokull surging glacier landsystem. Journal of Maps 3 (1), 349-367. https://doi. org/10.1080/jom.2007.9710850.

Evans, D.J.A., Twigg,D.R.,Rea,B.R.,Orton,C.2009.Surging glacierlandsystem of Tungnaárjökull, Iceland. Journal of Maps 5 (1), 134-151. https://doi.org/10.4113/jom.2009.1064.

Farnsworth, W.R., Ingólfsson, O., Retelle, M., Schomacker, A. 2016. Over 400 previously undocumented Svalbard surge-type glaciers identified. Geomorphology 264, 52-60. https:// doi.org/10.1016/j.geomorph.2016.03.025.

Ferrer, C., Mora, J., Arenillas, M. Navarro, J., Cobos, G. 2003. Evolución reciente de los aparatos glaciares del Pirineo español. Revista de Ingenieria Civil 131, 17-22.

Fischer, E.M., Luterbacher, J., Zorita, E., Tett, S.F.B., Casty, C., Wanner, H. 2007. European climate response to tropical volcanic eruptions over the last half millennium. Geophysical Research Letters 34 (5), 1-6. https://doi.org/10.1029/2006GL027992.

García-Ruiz, J.M., Martí-Bono, C. 2001. Mapa geomorfológico del Parque Nacional de Ordesa y Monte Perdido. Organismo Autónomo de Parques Nacionales, Ministerio de Medio Ambiente, Madrid, 106 pp.

García-Ruiz, J.M., Palacios, D., de Andrés, N., Valero, B., López-Moreno, J.I., Sanjuán, Y. 2014. Holocene and Little Ice Age glacial activity in the Marboré Cirque, Monte Perdido Massif, Central Spanish Pyrenees. The Holocene 24 (11), 1439-1452. https://doi. org/10.1177/0959683614544053.

Gaurier, L. 1921. Études glaciaires dans les Pyrénées françaises et espagnoles de 1900 a 1909. Garet-Haristoy, Pau.

Gómez de Llarena, J.1936. Algunos datos sobre el glaciar actual del Monte Perdido. Boletín de la Real Sociedad Española de Historia Natural 36, 327-343.

González-Trueba, J.J., Martín-Moreno, R., Martínez de Pisón, E., Serrano, E. 2008. Little Ice Age glaciation and current glaciers in the Iberian Pennsula. The Holocene 18 (4), 551-568. https:// doi.org/10.1177/0959683608089209.

Grove, J.M. 2004. Little Ice Ages: Ancient and modern. Routledge, London.

Grove, J.M., Gellatly, A.F. 1995. Little Ice Age fluctuations in the Pyrenees. Zeitschrift fur Gletscherkunde und Glazialgeologie 31, 199-206.

Haeberli, W., Kääb, A., Paul, F., Chiarle, M., Mortara, G., Mazza, A., Deline, P., Richardson, S. 2002. A surge-type movement at Ghiacciaio del Belvedere and a developing slope instability in the east face of Monte Rosa, Macugnaga, Italian Alps. Norwegian Journal of Geography 56, 104-111. http://doi.org/10.1080/ 002919502760056422.

Hernández-Pacheco, F., Vidal-Box, C. 1946. La tectónica y morfología del macizo del Monte Perdido y de las zonas de cumbres inmediatas en el Pirineo central. Pirineos 4, 69-108.

Hoinkes, H.C. 1969. Surges of the Vernagtferner in the Ötztal Alps since 1599. Canadian Journal of Earth Sciences 6, 853-861 . https://doi.org/10.1139/e69-086.

Hughes, P.D. 2007. Allostratigraphy/morphostratigraphy. In: S. Elias (Ed.), Encyclopedia of Quaternary Sciences. Elsevier, Amsterdam, pp. 2841-2846. https://doi.org/10.1016/B=-44452747-8/00076-4.

Hughes, P.D. 2010. Geomorphology and Quaternary stratigraphy: The roles of morpho-, litho-, and allostratigraphy. Geomorphology 123, 189-199. https://doi.org/10.1016/j.geomorph. 2010.07 .025 
Hughes, P.D. 2014. Little Ice Age glaciers in the Mediterranean mountains. Méditerranée, Review of Mediterranean Geography 122, 63-79. http://doi.org/10.4000/ mediterranee.7146.

Jones, P.D., Briffa, K.R., Barnett, T.P., Tett, S.F.B. 1998. High-resolution palaeoclimatic records for the last millennium: interpretation, integration and comparison with general circulation model control-run temperatures. The Holocene 8, 455-471. https://doi. org/10.1191/095968398667194956.

Jones, P.D., Mann, M.E. 2004. Climate over past millennia. Reviews of Geophysics 42, RG2002. Jones, P.D., Briffa, K.R., Barnett, T.P., Tett, S.F.B. 1998. High-resolution palaeoclimatic records for the last millennium: interpretation, integration and comparison with general circulation model control-run temperatures. The Holocene 8, 455-471. https://doi. org/10.1191/095968398667194956.

Jones, P.D., Mann, M.E. 2004. Climate over past millennia. Reviews of Geophysics 42, RG2002. https://doi.org/10.1029/2003RG000143.

Julián, A., Chueca, J. 1998. Le Petit Âge Glaciaire dans les Pyrénées Centrales Meridionales: estimation des paléotempératures á partir d'inférences géomorphologiques. Sud-Ouest Europeen 3, 79-88.

Kotlyakov, V. 2009. Global Warming and Surging Glaciers. UN Chronicles, 66, 3-44. https:// unchronicle.un.org/fr/article/le-r-chauffement-climatique-et-les-surges-glaciaires, 3 February 2017.

Lampre, F. 1994. La línea de equilibrio glaciar y los suelos helados en el Macizo de la Maladeta (Pirineo aragonés): evolución desde la Pequeña Edad de Hielo y situación actual. In: C. Martí Bono, J.M. García Ruiz, (Eds.), El glaciarismo surpirenaico: nuevas aportaciones. Geoforma Ediciones, Logroño, pp. 125-142.

Lampre, F. 1998. Estudio Geomorfológico de Ballibierna (macizo de la Maladeta, Pirineo aragonés): modelado glacial y periglacial. Consejo de Protección de la Naturaleza de Aragón, Zaragoza.

Le Roy Ladurie, E. 2004. Histoire humaine et comparée du climat. I. Canicules et glaciers XIIIeXVIIIe siécles. Fayard, Paris.

Le Roy Ladurie, E. 2006. Histoire humaine et comparée du climat. II. Disettes et révolutions 17401860. Fayard, Paris.

Le Roy Ladurie, E., Rousseau, D., Vasak, A. 2011. Les fluctuations du climat. De l'an mil á aujourd'hui. Fayard, Paris.

López-Moreno, J.I. 2000. Los glaciares del alto valle del Gállego (Pirineo Central) desde la Pequeña Edad del Hielo. Implicaciones en la evolución de la temperatura. Geoforma Ediciones, Logroño, $77 \mathrm{pp}$.

López-Moreno, J.I., Revuelto, J., Rico, I., Chueca, J., Julián, A., Serreta, A., Serrano, E., Vicente, S.M., Azorín, C., Alonso-González, E., García-Ruiz, J.M. 2016. Thinning of the Monte Perdido Glacier in the Spanish Pyrenees since 1981. The Cryosphere 10 (2), 681-694. https:// doi.org/10.5194/tc-10-681-2016.

Lugon, R., Delaloye, R., Serrano, E., Reynard, E., Lambiel, C., González-Trueba, J.J. 2004. Permafrost and Little Ice Age glaciers relationships: a case of study in the Posets Massif, Central Pyrenees, Spain. Permafrost and Periglacial Processes 15, 207-220. https://doi. org/10.1002/ppp.494.

Lukas, S. 2006. Morphostratigraphic principles in glacier reconstruction -A perspective from the British Younger Dryas. Progress in Physical Geography 30 (6), 719-736. https://doi. org/10.1177/0309133306071955.

Luterbacher, J., Werner, J.P., Smerdon, J.E., Fernández-Donado, L., González-Rouco, J., Barriopedro, D., Ljungqvist, F., Büntgen, U., Zorita, E., Wagner, S., Esper, J., McCarroll, D., Toreti, A., Frank, D., Jungclaus, J., Barriendos, M., Bertolin, C., Bothe, O., Brázdil, R., 
Dario, C., Dobrovolný, P., Gagen, M., García-Bustamante, E., Ge, Q., Gómez-Navarro, J., Guiot, J., Hao, Z., Hegerl, G., Holmgren, K., Klimenko, V., Martín-Chivelet, J., Pfister, C., Roberts, N., Schindler, A., Schurer, A., Solomina, O., von Gunten, L., Wahl, E., Wanner, H., Wetter, O., Xoplaki, E., Yuan, N., Zanchettin, D., Zhang, H., Zerefos, C. 2016. European summer temperatures since Roman times. Environmental Research Letters 11, 024001. https://doi.org/10.1088/1748-9326/11/2/024001.

Marti, R., Gascoin, S. Houet, T., Ribière, O., Laffly, D., Condom, T., Monnier, M., Schmutz, M., Camerlynck, C., Tihay, P., Soubeyroux, M., René, P. 2015. Evolution of Ossoue Glacier (French Pyrenees) since the end of the Little Ice Age. The Cryosphere 9, 1773-1795. https:// doi.org/10.5194/tc-9-1773-2015.

Martín-Moreno, R. 2004. Comparación de dos glaciares: Longyearbreen (Spitsbergen) y Monte Perdido (Pirineos). Características y evolución desde La Pequeña Edad del Hielo. Ería 63, 5-22.

Martín-Moreno, R. 2006. Estudio comparativo de formas y procesos glaciares y periglaciares desde la Pequeña Edad del Hielo. PhD Thesis, Universidad Autónoma de Madrid, Madrid.

Martínez de Pisón, E., Arenillas, M. 1988. Los glaciares actuales del Pirineo español. La nieve en el Pirineo Español, MOPU, Madrid, pp. 29-98.

Martínez de Pisón, E., Navarro, J., Martínez, R., Cantarino, I., Pedrero, A., Arenillas, M. 1995. Observaciones morfológicas sobre la evolución de los glaciares del Pirineo español entre 1982 y 1993. In: La Nieve en las Cordilleras españolas 1992/93. MOPTMA, Madrid, pp. 251-281.

Mateo, M., Gómez-Ortiz, A. 2000. Oscilaciones climáticas en el Holoceno Histórico. La Pequeña Edad de Hielo en el valle del Madriu. In: J.L. Peña, M. Sánchez-Fabre, M.V. Lozano (Eds.), Procesos y formas periglaciares en la montaña mediterránea. Instituto de Estudios Turolenses, Teruel, pp. 81-96.

Mateo,M.,Gómez-Ortiz,A. 2004.La Pequeña Edad del Hielo en Andorra: episodios morfogenéticos y su relación con la producción de cereales en Europa. Boletín de la Real Sociedad Española de Historia Natural (Sec. Geol.) 99 (1-4), 173-183.

Mateo, M., Gómez-Ortiz, A. 1998. El glaciarismo histórico. La Pequeña Edad del Hielo en el valle del Madriu (Andorra). In: A. Gomez Ortiz, F. Salvador Franch (Eds.), Investigaciones recientes de la geomorfología española. SEG-Geoforma Ediciones, Granada, pp. 397-406.

Nicolás, P. 1981. Morfología del circo de Tucarroya. Cuadernos de Investigación Geográfica 6 (1-2), 51-80. https://doi.org/10.18172/cig.884.

Nicolás, P. 1986. Morfología de un aparato glaciar: el glaciar nororiental del Monte Perdido. Pirineo de Huesca. In: Atlas de Geomorfología, Alianza, Madrid, pp. 189-209.

Nussbaumer, S.U., Zumbühl, H.J. 2012. The Little Ice Age history of the Glacier des Bossons (Mont Blanc massif, France): A new high-resolution glacier length curve based on historical documents. Climatic Change 111 (2), 301-334. https://doi.org/10.1007/s10584-011-0130-9.

Nussbaumer, S.U., Zumbühl, H.J., Steiner, D. 2007. Fluctuations of the Mer de Glace (Mont Blanc area, France) AD 1500-2050: an interdisciplinary approach using new historical data and neural network simulations. Zeitschrift fur Gletscherkunde und Glazialgeologie 40, 1-183. http://doi.org/10.1029/2004GL02025510.

Oliva, M., Gómez-Ortiz, A. 2012. Late Holocene environmental dynamics and climate variability in a Mediterranean high mountain environment (Sierra Nevada, Spain) inferred from lake sediments and historical sources. The Holocene 22 (8), 915-927. https://doi. org/10.1177/0959683611434235.

Oliva, M., Serrano, E., Gómez-Ortiz, A., González-Amuchástegui, M.J., Nieuwendam, A., Palacios, D., Pellitero-Ondicol, R., Pérez-Alberti, A., Ruiz-Fernández, J., Valcárcel, M., Vieira, G., Antoniades, D. 2016. Spatial and temporal variability of periglaciation of the 
Iberian Peninsula. Quaternary Science Reviews 137, 176-199. https://doi.org/10.1016/j. quascirev.2016.02.017.

Oliva, M., Ruiz-Fernández, J., Barriendos, M., Benito, G., Cuadrat, J.M., García-Ruiz, J.M., Giralt, A., Gómez-Ortiz, A., Hernández, A., López-Costas, O., López-Moreno, J.I., LópezSáez, J.A., Martínez-Cortizas, M., Moreno, A., Prohom, M., Saz, M.A., Serrano, E., Tejedor, E., Trigo, R., Valero, B. (2018). The Little Ice Age in the Iberian mountains. Earth-Science Reviews, 177, 175-208. http://doi.org/10.1016/j.earscirev.2017.11.010.

Prohom, M., Barriendos, M., Sánchez-Lorenzo, A. 2016. Reconstruction and homogenization of the longest instrumental precipitation series in the Iberian Peninsula (Barcelona, 1786-2014). International Journal of Climatology 36 (8), 30723087. https://doi.org/10.1002/joc.4537.

Ramond de Carbonnières, L. 1802. Voyage dans les Pyrénées. Observations dans les Pyrénées. Lardanchet, Lyon, $210 \mathrm{pp}$.

René, P. 2001. Actualisation des observations sur les glaciers des Pyrénées Centrales franÇaises. Journal du Parc National des Pyrenees 10, 9-10.

René, P. 2003. Les glaciers des Pyrénées françaises. Boletín Glaciológico Aragonés 4, 31-68.

René, P. 2011. Régression des glaciers Pyrénéens et transformation du paysage depuis le Petit Âge Glaciaire. Sud-Ouest Européen 32, 5-19. https://doi.org/10.4000/soe.639.

René, P. 2013. Glaciers de Pyrenees. Le rechauffement climatique en images. P.N. des Pyrénées, Cairn Editions, Pau.

Rico, I., Izaguirre, E., Serrano, E., López-Moreno, J.I. 2017. Current glacier area in the Pyrenees: an updated assessment 2016. Pirineos, 172, e029. http://doi.org/10.3989/Pirineos.2017.172004.

Russell, H. 1908. Souvenirs d'un montagnard. Vignancour, Pau.

Saz, M.A., Creus-Novau, J. 2001. El clima del Pirineo centro-oriental desde el siglo XV: estudio dendroclimático del observatorio de Capella. Boletín Glaciológico Aragonés 2, 37-79.

Saz, M.A. 2003. Temperaturas y precipitaciones en la mitad norte de España desde el siglo XV. Estudio dendroclimático. Publicaciones del Consejo de Protección de la Naturaleza de Aragón, Zaragoza, 293 pp.

Schrader, F. 1936. Sur l'étendue des glaciers des Pyrenees 1894. Pyrenees, 201-221.

Serrano, E. 1991. Glacial evolution of the Upper Gállego valley (Panticosa Mountains and Ribera de Biescas, Aragonese Pyrenees, Spain). Pirineos 138, 83-104. https://doi.org/10.3989/ pirineos.1991.v138.191.

Serrano, E. 1995. Geomorfología de la Sierra de Tendeñera. Ería 37, 143-158.

Serrano, E. 1996. Líneas de equilibrio glaciar, glaciares rocosos y paleoambiente postglaciar en la alta montaña pirenaica (macizo de Panticosa, Pirineo aragonés). In: A. Pérez-Alberti, P. Martini, W. Chesworth, P. Ramil-Rego (Eds.), Dinámica y evolución de medios cuaternarios. Xunta de Galicia, Santiago de Compostela, pp. 157-170.

Serrano, E., Agudo, C. 1988. La deglaciación del circo de los Ibones Azules. Estudio glaciomorfológico. Cuaternario y Geomorfología 2, 115-123.

Serrano, E., Martínez de Pisón, E. 1994. Geomorfología y evolución glaciar en el Pirineo aragonés oriental. In: C. Martí Bono, J.M. Gracía Ruiz (Eds.), El glaciarismo surpirenaico: nuevas aportaciones. Geoforma Ediciones, Logroño, pp. 33-64.

Serrano, E. 1998. Geomorfología del Alto Gállego (Pirineo aragonés). Institución Fernando El Católico, Zaragoza, 501 pp.

Serrano, E., Agudo, C., González-Trueba, J.J. 2002. La deglaciación de la alta montaña. Morfología, evolución y fases morfogenéticas glaciares en el macizo del Posets (Pirineo Aragonés). Cuaternario y Geomorfología 16 (1-4), 111-126.

Serrano, E., Morales, C., González-Trueba, J.J., Martin-Moreno, R. 2009. Cartografía del permafrost de montaña en los Pirineos españoles. Finisterra 45, 45-54. https://doi. org/10.18055/Finis1376. 
Serrano, E., González-Trueba, J.J., Sanjosé, J.J. 2011. Dinámica, evolución y estructura de los glaciares rocosos de los Pirineos. Cuadernos de Investigación Geográfica 37 (2), 145-170. https://doi.org/10.18172/cig.1260.

Sevestre, H. 2015. Surge-type glaciers: controls, processes and distribution. $\mathrm{PhD}$ thesis. Faculty of Mathematics and Natural Sciences, University of Oslo, No. 1671 (ISSN-1501-7710).

Sevestre, H., Benn, D.I. 2015. Climatic and geometric controls on the global distribution of surgetype glaciers: implications for a unifying model of surging. Journal of Glaciology 61, 646662. https://doi.org/10.3189/2015JoG14J136.

Sharp, M.J. 1985. "Crevasse-fill" ridges: a landform type characteristic of surging glacier? Geografiska Annaler 67A, 213-220. https://doi.org/10.2307/521099.

Striberger, J., Jbörck, S., Benediktsson, I.Ö., Snowball, I., Uvo, C.B., Ingólfsson O., Kjær, K.H. 2011. Climatic control on the surge periodicity of an Icelandic outlet glacier. Journal of Quaternary Science 26 (6), 561-565. https://doi.org/10.1002/jqs.1527.

Tejedor, E., de Luis, M., Cuadrat, J.M., Esper, J., Saz, M.A. 2016. Tree-ring-based drought reconstruction in the Iberian Range (east of Spain) since 1694. International Journal of Biometeorology 60 (3), 361-372. https://doi.org/10.1007/s00484-015-1033-7.

Tejedor, E., Saz, M.A., Cuadrat, J.M., Esper, J., de Luis, M. 2017. Temperature variability of the Iberian Range since 1602 inferred from tree-ring records. Climate of the Past 13, 93-105. https://doi.org/10.5194/essd-2017-35.

Tonnellé, A. 1977. Trois mois dans les Pyrénées en 1858. Am. Liv. Pyrenean, Pau.

Trigo, R.M., Vaquero, J.M., Alcoforado, M.J., Barriendos, M., Taborda, J., García-Herrera, R., Luterbacher, J. 2009. Iberia in 1816, the year without a summer. International Journal of Climatology 29, 99-115. https://doi.org/10.1002/joc.1693.

Ventura, J. 2016. Identificación e inventario de potenciales glaciares rocosos activos en los Pirineos mediante fotointepretación en visores cartográficos $2 \mathrm{~d}$ y $3 \mathrm{~d}$ : primeros resultados. Polígonos, Revista de Geografía 28, 95-122.

Zumbühl, H.J., Steiner, D., Nussbaumer, S.U. 2008. 19th century glacier representations and fluctuations in the central and western European Alps: An interdisciplinary approach. Global and Planetary Change 60 (1-2), 42-57. https://doi.org/10.1016/j.gloplacha.2006.08.005. 